\title{
Alterations in the motor neuron-Renshaw cell circuit in the Sod1 1993A mouse model
}

\author{
Hanna Wootz ${ }^{1}$, Eileen FitzSimons-Kantamneni ${ }^{2, \&}$, Martin Larhammar ${ }^{1, \&}$, Travis M. \\ Rotterman ${ }^{6}$, Anders Enjin ${ }^{1}$, Kalicharan Patra ${ }^{1}$, Elodie Andre ${ }^{1}$, Brigitte van Zundert ${ }^{3,4}$, Klas \\ Kullander ${ }^{1,5,{ }^{*}}$, and Francisco J. Alvarez ${ }^{2,6,{ }^{*}}$ \\ ${ }^{1}$ Department of Neuroscience, Uppsala University, 75124 Uppsala, Sweden \\ ${ }^{2}$ Department of Neurosciences, Cell Biology, and Physiology, Wright State University, Dayton, \\ Ohio 45435, USA \\ ${ }^{3}$ McGovern Institute for Brain Research, Massachusetts Institute of Technology, Cambridge, \\ Massachusetts 02139, USA \\ ${ }^{4}$ Center for Biomedical Research, Faculty of Biological Sciences and Faculty of Medicine, \\ Universidad Andres Bello, Santiago, Chile \\ ${ }^{5}$ Science for Life Laboratory, Uppsala University, 75124 Uppsala, Sweden \\ ${ }^{6}$ Department of Physiology, Emory University, Atlanta, Georgia 30322, USA
}

\section{Abstract}

Motor neurons become hyperexcitable during progression of amyotrophic lateral sclerosis (ALS). This abnormal firing behavior has been explained by changes in their membrane properties, but more recently it has been suggested that changes in premotor circuits may also contribute to this abnormal activity. The specific circuits that may be altered during development of ALS have not been investigated. Here we examined the Renshaw cell recurrent circuit that exerts inhibitory feedback control on motor neuron firing. Using two markers for Renshaw cells (calbindin and Chrna2, cholinergic nicotinic receptor subunit alpha2), two general markers for motor neurons (NeuN and VAChT, vesicular acethylcholine transporter) and two markers for fast motor neurons (Chondrolectin and Calca, calcitonin-related polypeptide alpha), we analyzed the survival and connectivity of these cells during disease progression in the Sod1 ${ }^{G 93 A}$ mouse model. Most calbindin-immunoreactive (IR) Renshaw cells survive to end-stage but downregulate postsynaptic Chrna2 in presymptomatic animals. In motor neurons, some markers are downregulated early (NeuN, VAChT, Chondrolectin) and others at end-stage(Calca). Early downregulation of presynaptic VAChT and Chrna2 was correlated with disconnection from Renshaw cells as well as

Corresponding authors: Co-corresponding authors are Drs. Klas Kullander and Francisco J. Alvarez: Francisco J. Alvarez: Department of Physiology, Emory University; Whitehead Research Building, Room 642; 615 Michael Street, Atlanta, GA, 30322-3110.

Francisco.j.alvarez@emory.edu, Klas Kullander: Department of Neuroscience,Uppsala University, Box 587, 75123 Uppsala, Sweden. klas.kullander@neuro.uu.se.

$\&_{E}$ F-K and ML contributed equally to this work

Conflict of Interest

There are no known conflicts of interest that would have inappropriately influenced this work.

Role of Authors

- $\quad$ Study concept and design: FJA, KK, HW, EF-H

- $\quad$ Acquisition of dataand statistical analyses: HW, EF-H, ML, AE, KP, EA, FJA, BvZ.

- $\quad$ Drafting and critical revision of manuscript: HW, FJA, KK, BvZ, FJA.

- $\quad$ Study supervision: FJA \& KK. 
major structural abnormalities of motor axon synapses inside the spinal cord. Renshaw cell synapses on motor neurons underwent more complex changes, including transitional sprouting preferentially over remaining NeuN-IR motor neurons. We conclude that the loss of presynaptic motor axon input on Renshaw cells occurs at early stages of ALS and disconnects the recurrent inhibitory circuit, presumably resulting in a diminished control of motor neuron firing.

\section{Keywords}

Amyotrophic Lateral Sclerosis; recurrent inhibition; VAChT; synapses

\section{Introduction}

Several neurodegenerative diseases including Parkinson's, Alzheimer's and Huntington's are characterized by synaptic circuit alterations that contribute to early symptoms and sometimes correlate with disease progression better than cell loss (Coleman and Yao, 2003; Bezard et al., 2003; Milnerwood and Raymond 2010). Synaptic changes lead to modifications in circuit function that can temporarily alleviate symptoms, but in other situations they aggravate disease progression (Palop et al., 2006). Inhibitory interneurons play critical roles during these modifications and can act as a protective "circuit buffer" that corrects for abnormal activity (Palop et al., 2006). Their failure frequently correlates with disease onset and vulnerability. For example, loss of inhibitory synaptic activity has been shown to alter cortical neuron function at the onset of disease in a mouse model of Huntington's disease (Spampanato et al., 2008) and cellular vulnerability to $\beta$-amyloid in Alzheimer's disease correlates with the amount of inhibition that different neurons receive (Graf and Kater, 1998; Palop et al., 2005).

In amyotrophic lateral sclerosis (ALS), loss of muscle control is due to dysfunction followed by degeneration and ultimately death of motor neurons. However, not all motor neurons are equally susceptible (Kanning et al., 2010), a fact that is being exploited to investigate disease mechanisms and potential protective properties. One extensively studied mechanism of motor neuron cell death is excitotoxicity due to excessive glutamate release(Cleveland and Rothstein, 2001; Van Den Bosch et al., 2006). Imbalances in inhibition could exacerbate this process and it has been reported that inhibitory receptors on ALS-resistant motor neurons display properties that strengthen glycinergic and GABAergic neurotransmission (Lorenzo et al., 2006). Moreover, motor neuron loss in ALS patients is highly correlated with a reduction of glycinergic receptors (Hayashi et al., 1981), and a lower efficacy of inhibitory inputs has been demonstrated in cortex and in cultures of embryonic spinal motor neurons using two different animal models of ALS (Nieto-Gonzalez et al., 2011; Chang and Martin 2011). Lower inhibitory control may increase the excitotoxic burden of motor neurons during disease progression and there is evidence for increased excitatory activity and network drive onto motor neurons coinciding with the onset of tremors in the Sod1 ${ }^{G 93 A}$ mouse model (van Zundert et al., 2008; Jiang et al., 2009; reviewed in van Zundert et al., 2012). Correspondingly, experimental decrease of vesicular glutamate transporter 2 (VGLUT2) expression, which is responsible for loading glutamate into the synaptic vesicles of many premotor excitatory synapses, protects motor neurons in the same model (Wootz et al., 2010). It is therefore possible that disinhibition contributes to ALS motor neuron pathology, but if so, it remains to be established by which inhibitory circuits and interneurons.

An important and relatively simple circuit that controls motor neuron firing is the recurrent inhibitory circuit established between Renshaw cells and motor neurons. Renshaw cells receive synaptic inputs from intraspinal collaterals of motor axons and once activated, 
inhibit the same motor neurons and close synergists (Renshaw, 1946; Eccles et al., 1954; Fyffe, 1991; reviewed in Alvarez and Fyffe, 2007). In this manner, Renshaw cells slow down and stabilize motor neuron firing and shape input/output relations to excitatory drive (reviewed in Windhorst, 1996). Interestingly, ALS patients show decreased recurrent inhibition suggesting transmission impairment in this inhibitory control circuit (Raynor and Shefner, 1994). This might occur through Renshaw cell death or pathology, or because of synaptic dysfunction. Current data suggest that Renshaw cells are largely spared, particularly at early stages of the disease (Morrison et al., 1996, Knirsch et al., 2001; Chang and Martin, 2009). Here we confirm this conclusion and in addition provide new evidence revealing the structural degeneration and retraction of motor axon synapses on Renshaw cells preceding motor neuron degeneration. This synaptic pathology is paralleled by a reduction in gene expression of presynaptic VAChT (vesicular acetylcholine transporter responsible for loading acetylcholine into synaptic vesicles)and postsynaptic chrna2 (chrna2 encodes the a 2 subunit of a nicotinic receptor present specifically on Renshaw cells; Ishii et al., 2005), In addition, we detected early changes in expression of the "fast" motor neuron specific chondrolectin gene, suggesting that this population, which is responsible for the majority of motor inputs received by Renshaw cells (Cullheim and Kellerth, 1978), is affected at very early stages of disease. Together, these data suggest that the recurrent inhibitory circuit is altered in the late presymptomatic period by a deficit in the motor axon synapses on Renshaw cells.

\section{Materials and Methods}

\section{Mouse line}

We used hemizygous transgenic B6SJL mice carrying a high copy number of mutant human Superoxide dismutase 1 ( $\mathrm{h}$ Sod $1^{G 93 A}$ ) (Jackson laboratory, Bar Harbor, ME, USA). These hSOD1 ${ }^{\mathrm{G} 93 \mathrm{~A}}$ mice develop signs of neuromuscular deficits (tremor of the legs and loss of extension reflex of the hind paws) and have an average lifespan of 120-150 days (Gurney et al., 1994; Chiu et al., 1995; Scott et al., 2008).Age matched or end stage Sod1 ${ }^{G 93 A-/-}$ littermates were used as WT controls. Animals were obtained from colonies at the Massachusetts Institute of Technology (for immunohistochemistry, IHC) or at Uppsala University (for in situ hybridization, ISH, studies). To harvest fixed spinal cords the animals were perfused with $4 \%$ paraformaldehyde diluted in $0.1 \mathrm{M}$ phosphate buffer $(\mathrm{PB}, \mathrm{pH}, 7.4)$ and postfixed overnight. Animals prepared for electron microcopy where perfused in $4 \%$ paraformaldehyde and $0.5 \%$ glutaraldehyde and postfixed for 4 hours. All animal procedures were approved by the appropriate local Swedish ethical committee (permit 248/11) and Massachusetts Institute of Technology.

\section{Immunohistochemistry}

The lumbar enlargement of the spinal cord was sectioned at $50 \mu \mathrm{m}$ in a freezing slidingmicrotome or vibratome and processed free-floating. Sections were blocked for 1 hour in normal horse or donkey serum (1:10, in 0.01 M PBS with $0.1 \%$ TritonX-100: PBSTX) and incubated in primary antibodies overnight. The primary antibodies used were: mouseanti-NeuN 1:1000 (Chemicon, USA), rabbit anti-calbindin D-28k antibody 1:1000 or 1:2000 (CB 38, Swant, Switzerland), guinea pig anti-VAChT 1:500 or 1:1000 (Chemicon), goat anti-VAChT 1:1000, 1:4000 or 1:5000 (Chemicon), goat anti-choline acetyltranferase (ChAT) 1:250 (Millipore)and mouse anti-bassoon 1:4000 (Enzo Life Sciences). The specificity of these antibodies has been thoroughly tested (see below and Table 1). All antibodies were diluted in PBS-TX with $0.1 \%$ or $0.3 \%$ TritonX-100. Following primary antibody incubations the sections were washed in PBS and immunoreactivities revealed with Fluorescein isothyocyanate (FITC) or cyanine (Cy3or Cy5) conjugated antibodies (dilution 1:50 or 1:100 in PBS-TX) raised in donkey against IgGs of the appropriate species (Jackson 
Laboratories, USA). The sections were washed in PBS, mounted on gelatin-coated slides, and cover-slipped with Vectashield (Vector labs, USA).

\section{Antibody specificity}

See summary in table 1. Calbindin antibodies: The rabbit polyclonal antibody used was raised against rat recombinant calbindin D28k and detects a single $28 \mathrm{kDa}$ band in western blots of brain homogenates of tissue originating from several species including rat, rabbit, guinea pig, mouse, chicken and zebrafish (information provided by the manufacturer: Swant, Bellinzona, Switzerland) and does not stain any structures in the spinal cord of calbindin-D28k knockout mice (Francisco J. Alvarez, unpublished). Calbindin expression in Renshaw cells was further confirmed by the perfect overlap between immunocytochemistry and expression of its mRNA. VAChT antibodies: We used two polyclonal antibodies raised in guinea pig and goat, respectively, each against a similar, but not identical, sequence in the C-terminus (see Table 1). In western blots, the guinea pig antibody reacted with a single band in rat brain homogenates that corresponded with the predicted size of VAChT(information provided by the manufacturer: Chemicon (now Millipore), USA). Dual immunofluorescence preparations with choline acetyl transferase (Chat) and guineapig antiVAChT in the ventral spinal cord resulted in dual-labeling of motoneurons in lamina IX and dual immunofluorescence with both the guinea pig and goat anti-VAChT antibodies resulted in virtually complete overlap of staining (Francisco J. Alvarez, unpublished observations). Both produced the same well-described pattern of immunoreactive punctae in the spinal cord reported by us (Alvarez et al., 1999) and others (see for example: Arvidsson et al., 1997; Hellstrom et al.,1999). In addition cholinergic cells bodies are weakly labeled by both VAChT antibodies in exactly the same cells revealed with ISH for VAChT (see below). NeuN antibody. We used a mouse monoclonal antibody raised against neuronal nuclei. Only one monoclonal antibody exists (A60, Mullen et al., 1992) and the product we used was obtained through Chemicon (see Table 1). The antibody recognizes the transcription factor Fox-3 in fixed tissue. In western blots of rat brain homogenates the antibody recognizes two bands that respectively correspond to Fox-3 (40-50 kDa band) and synapsin I (70 kDa band), both characterized using immunoprecipitation, mass spectrophotometry and expression in heterologous cells (Kim et al., 2009). In fixed tissues and cells, however, synapsin I is never detected as demonstrated by lack of evidence of NeuN-immunoreactivity in synaptic boutons or synaptic vesicles. The immunostaining of neuronal nuclei obtained in the spinal cord is identical to that reported previously by us (Alvarez et al., 2005; Shneider et al., 2009; Siembab et al., 2010) and that reported in spinal cord atlases (Watson et al., 2009). ChAT antibody: The commercial ChAT antibody used here (Millipore) was generated against the enzyme isolated from human pancreas. In western blots of mouse lysates it gives a single band of $68-70 \mathrm{kDa}$ (information provided by Millipore). The antibody gives an immunoreaction in the spinal cord consistent with the distribution of cholinergic neurons (Watson et al., 2009). Bassoon antibody: We obtained commercially (Enzo Life Sciences)a widely used mouse monoclonal antibody produced in the University of Alabama hybridoma facility against the protein product of a 733-nucleotide long cDNA known as sap7f (Dieck et al., 1998). This sequence corresponds with residues 738-1035 of rat bassoon and is shared with mouse. The antibody detects a band of approximately 400 $\mathrm{kDa}$ in western blots of rat brain lysates. Additional bands between 97 and $400 \mathrm{kDa}$ are also identified and considered to be proteolytic degradation products of bassoon. No immunoreactivity is found in brain sections from animals lacking exons 4 and 5 of bassoon, which includes the sequence recognized by this monoclonal antibody (Altrock et al., 2003).

\section{In-situ hybridization and double in-situ hybridization and immunohistochemistry}

In situ hybridization (ISH) was performed on $60 \mu \mathrm{m}$ free-floating lumbar spinal cord sections. RNA digoxigenin-11-UTP probes correspond to the following genes: VAChT 
(Slc18a3, nucleotides 1533-2418, NM_021712.2), Chodl (nucleotides 1914-2530

NM_139134.3), Calca (nucleotides 381-1014, NM_001033954.3), Chrna2 (nucleotides

2145-3540, BC011490) and Calb1 (calbindin 28K, nucleotides 561-1601, NM_009788).

Free-floating ISH was performed as previously described (Enjin et al., 2010). Hybridized probes were visualized with alkaline phosphatase using BM purple (Roche, Germany) chromogenic substrate or SIGMAFAST Fast Red TR/Naphthol AS-MX (Sigma-Aldrich) fluorescent substrate developed for $>12$ hours at $37^{\circ} \mathrm{C}$.Immunohistochemistry (IHC) was done after fluorescent ISH using the same rabbit anti-calbindin antibody as above diluted 1:5000 in PBS containing 1x blocking reagent (Roche) and incubated for $48 \mathrm{~h}$ at $4{ }^{\circ} \mathrm{C}$. Sections were washed in PBS and incubated with secondary antibody Alexa Fluor 647 antirabbit IgG (Invitrogen, USA) for $1.5 \mathrm{~h}$ at room temperature. Sections were mounted on slides using 2.5\% DABCO (Sigma) in glycerol containing 0.1M Tris (pH 8.6) or Mowiol 488 (Roth, Germany).

\section{Cell counting and statistics}

Cell counts in IHC experiments were obtained by plotting cells with different markers in Neurolucida (version 6.0, Microbrightfield, Inc., USA) coupled to a BX51 Olympus epifluorescence microscope fitted with a digital color camera (Microfire CCD, Optronics, USA) and a motorized stage (Ludl Electronics, USA). Motor neurons were identified as large (diameter $>30 \mu \mathrm{m}$ ) NeuN-IR neuronsor by their ChAT-immunoreactivity. Renshaw cells were identified as neurons with strong calbindin-immunoreactivity in the most ventral region of LVII and LIX. Interneurons were identified as small (diameter $<30 \mu \mathrm{m}$ ) NeuN-IR neurons within the ventral horn. The boundaries of the ventral horn were established by drawing a horizontal line laterally from a point in the middle of the most dorsal aspect of the central canal and a vertical line ventrally from that same location, and using the border of the gray and white matter for the remaining sides. Within these boundariesall motor neurons, interneurons and Renshaw cells, with a visible nucleolus, were plotted and counted.

NeuN immunoreactivity in ChAT-IR lateral column motor neurons of lumbar 4 and 5 segments was estimated by imaging ChAT (FITC) and NeuN (Cy3) immunofluorescence in four ventral horns per animal with an Olympus FV1000 confocal microscope (20x1). Three 3 -month old $\operatorname{Sod} 1^{G 93 A}$ animals and three age-matched WT littermates were studied. The confocal stacks were imported into Image-Pro Plus (ver. 7.0 Media Cybernetics) and the cell body of every ChAT-immunoreactive neuron in the LMC was outlined in the optical plane displaying a nucleolus. The cross sectional area and average NeuN immunofluorescence (resolved at 8 bits $=0-255$ gray levels)was measured.

Chromogenic ISH stainings were analyzed with a Leica MZ16F dissection microscope with DFC300FX camera and FireCam software (Leica Microsystems). Combined fluorescent ISH and IHC were analyzed using Zeiss LSM 510 meta confocal microscope and LSM 510 software (Carl Zeiss, Germany). VAChT, Chodl and Calca positive cells in the ventral horn were counted, and cells expressing Chrna 2 and $C a l b 1$ were counted in the defined Renshaw cell area (100 $\mu \mathrm{m}$ into grey matter from ventral rim in lamina VII and lamina IX), of lumbar spinal cords.

Quantitative data in IHC and ISH analyses was comparedusing analysis of variance tests (ANOVA) followed by Bonferroni's corrected tests. Error bars represent SEM and $\mathrm{p}<0.05$ was considered significant. In the figures “**” $=p<0.05, “ * * ”=p<0.01$, “****" $=p<0.001$.

\section{Analysis of VAChT-IR contacts on Renshaw cell dendrites}

Calbindin-IR Renshaw cell bodies and dendrites and their VAChT-IR contacts were imaged at high magnification (60X objective; digital zoom X2) in an Olympus FX confocal 
microscope system and the stacks of confocal images (z-steps $0.5 \mu \mathrm{m}$ ) imported into Neurolucida. Each neuron was traced from 3D confocal image stacks and VAChT-IR puncta contacting Renshaw cell dendrites were plotted along the tracing. The number of VAChT-IR contacts and several dendrite characteristics including their number, length and surface area were determined with Neuroexplorer software (version 4.0, Microghright field, Inc.). From these data the average density of VAChT-IR contacts on the dendrites of calbindin-IR Renshaw cells was calculated (number of contacts $/ 100 \mu \mathrm{m}$ length of dendrites) for each age, being careful that similar amounts of dendrite were imaged per cell. Similar results were obtained when correcting for dendrite surface (not shown). Analyses were restricted to field of views of 133 X $100 \mu \mathrm{m}$ around the cell bodies. Dendrites coursing in the X-Y plane usually extend beyond the field of view while dendrites oriented in $\mathrm{Z}$ are limited by the thickness of the section. Therefore in the different animals the maximum length of dendritic segments analyzed varied, on average, from 89 to $138 \mu \mathrm{m}$ from the cell soma. This compartment was taken as representative of VAChT-innervation (see also Mentis et al., 2006 and Siembab et al., 2010). We analyzed a total of 11 to 15 Renshaw cells in two Sod1 ${ }^{G 93 A}$ or WT animals at each age (1,2,3, and 4 months). Statistical analyses between different ages were performed with one-way ANOVA. Comparisons between $\operatorname{Sod1}^{G 93 A}$ and age-matched WT Renshaw cells were carried out using Bonferroni-corrected t-tests. Error bars and significance were as above.

\section{Bassoon containing calbindin-IR contacts around ChAT motor neuron cell bodies}

Confocal images of calbindin axons, ChAT motor neuron cell bodies and bassoon presynaptic active zones were obtained in an FV1000 Olympus microscope (60X objective; digital zoom X2.5). Each motor neuron cell body was sampled in a middle cell body plane (containing a nucleolus)and 4 additional optical planes, two above and two below separated by at least $2 \mu \mathrm{m}$ in $\mathrm{z}$. The number of calbindin-IR varicosities in apposition to the motor neuron surface in these five optical planes was counted and the percentage of contacts with bassoon calculated. Bassoon containing varicosities were considered synaptic and a density estimated per $100 \mu \mathrm{m}$ of linear membrane on ChAT motor neurons from three Sod1 ${ }^{G 93 A}$ animals of three months of age and three age-matched WT littermates ( $\mathrm{n}=12$ motor neurons analyzed per animal). A box and whisker plot was constructed with the data from all motor neurons pooled together and outliers (i.e., points beyond the 10 and 90 percentiles of the population) plotted on the graph (Fig. 6e). Sod1 ${ }^{G 93 A}$ motor neurons and WTs were comparedusing a t-test. Significance is set and represented in the graph as above.

\section{Calbindin-IR contacts around NeuN motor neuron cell bodies}

Confocal images of calbindin-IR axons surrounding NeuN-IR motor neurons were imaged with confocal microscopy(FX instrument, 60X objective; digital zoom X3). Analyses were carried out in Fluo view and each motor neuron was sampled as explained above. We analyzed a total of 15 to 24 motor neuron cell bodies in two $\operatorname{Sod1} 1^{G 93 A}$ or WT animals at each age (1, 2, 3, and 4 months). A WT average was obtained per age and each WT and Sod $1^{\text {G93A }}$ motor neuron was normalized to the age-matched WT average to obtain a percentage change and the standard deviations (S.D.) of these changes. Thus, in figure $6 \mathrm{i}$ error bars represent S.D. Sod1 ${ }^{G 93 A}$ motor neurons were compared to age-matched WTs using t-tests. Significance is set and represented in graph as above.

\section{Electron microscopy}

Fifty micrometer thick vibratome sections were obtained and processed for electron microscopy immunocytochemistry using either a single VAChT immunogold-silver immunoreaction in two 2.5 month old $\operatorname{Sod} 1^{G 93 A}$ animals or a dual VAChT immunogoldsilver and calbindin ABC-peroxidase immunoreactions in WTs. Sections were blocked for 1 hr each with $1 \% \mathrm{NaBH}_{4}$ in PBS and in 1:10 normal donkey serum in PBS. Then they were 
incubated overnight with a guinea pig anti-VAChT (1:200; Chemicon) and in the case of WTs combined with rabbit anti-calbindin (1:500; Swant) diluted in PBS. VAChTimmunoreactive sites were revealed with immunogold silver. Sections were first incubated with goat anti-guinea pig antibodies coupled to $1.4 \mathrm{~nm}$ gold particles and then amplified with HQ silver enhancement (Nanoprobes). If a calbindin immunoreaction was also present this was revealed using $\mathrm{ABC}$ peroxidase kits (Vector Laboratories) and reacted with $0.02 \%$ DAB and $0.01 \% \mathrm{H}_{2} \mathrm{O}_{2}$ (5-15 mins). The sections were washed overnight, osmicated (20 min in $0.2 \%$ OsO4 in $0.1 \mathrm{M} \mathrm{PB}$ ), dehydrated in ascending alcohols, and flat embedded in EponAraldite resin. Ultrathin sections were counterstained with uranyl acetate and lead citrate and examined in a Phillips $208 \mathrm{~S}$ electron microscope at $70 \mathrm{kV}$. Digital images were obtained with an AMT xr611 camera (Advanced Microscopy Techniques).

\section{Image composition}

ISH images were pseudo colored and adjusted for brightness and contrast using Volocity software (Improvision, UK) and arranged with Adobe Illustrator CS4. IHC and electron microscopy images were similarly optimized using Image Pro Plus (Media Cybernetics, USA) and organized using Corel Draw 12. Image sharpness was sometimes improved using a high-gauss filter (Image Pro Plus).

Magenta-green version of dual-colr fluorescence shown in figures 1,2 and 4 are shown as corresponding supplementary figures 1,2 and 3 .

\section{Results}

\section{NeuN immunoreactivity downregulation in $\alpha$-motor neurons coincides with onset of muscle weakness}

In the $\operatorname{Sod} 1^{G 93 A}$ line used in this study, muscle weakness appears around 90 days (3 months) and becomes severe by 120 days (4 months) with death within days (Gurney et al., 1994). Similar to other studies using this same line (Chiu et al., 1995), early symptomatic animals are characterized by hindlimb tremor and hindlimb flexion when pulled from the tail, while end-stage is characterized by severe hindlimb paresis with marked muscle atrophy. Muscle weakness was tested using a simple hanging wire test (Miana-Mena et al., 2005) and scored as 1 at the onset of symptoms and 4 when the animal had lost all strength. The onset of muscle weakness in these animals has been correlated with disconnection of peripheral motor axons with target muscles (Frey et al., 2000; Fischer et al., 2004; Schaefer et al., 2005; Pun et al., 2006). Motor axotomy causes downregulation of NeuNimmunoreactivity (IR) (McPhail et al. 2004; Alvarez et al., 2011), while NeuN-IR recovery is coincident with peripheral regeneration and muscle reconnection (Alvarez et al., 2011). Thus, NeuN was used here as an early marker of a-motor neuron disease and possibly disconnection with muscle. Downregulation of NeuN immunoreactivity precedes apoptosis and loss of cholinergic motor neurons, revealed with choline acetyltransferase antibodies (ChAT, see below). In addition, sampling of motor neurons with NeuN has the additional advantage of focusing the analysis to a-motor neurons because NeuN is not expressed, or expressed at very low levels in $\gamma$-motor neurons (Shneider et al., 2009; Friese et al., 2009). The sections were dual immunolabeled to compare parallel changes in motor neuron NeuN and Renshaw cell calbindin immunoreactivities (figure 1).

NeuN-IR motor neurons in wild type (WT) and Sod1 $1^{G 93 A}$ animals of 1, 1.5 and 2 months of age appear normal and readily identifiable as large size neurons (diameter $>30 \mu \mathrm{m}$ ) located in Lamina (L) IX (Figures 1a and e). Large NeuN-IR motor neurons in lateral LIX were significantly reduced in number in 3 and 4 months old $\operatorname{Sod} 1^{G 93 A}$ animals (figures $1 \mathrm{c}$,f and g). Because the number per section of WT NeuN-IR motor neuron profiles (i.e., containing a 
nucleolus) slightly decreased with age ( $\mathrm{p}<0.001$ ANOVA, see next paragraph), we compared NeuN-IR motor neuron numbers in Sod1 ${ }^{G 93 A}$ animals (pooled data from $\mathrm{n}=2-4$ Sod $1^{G 93 A}$ animals/45-115 ventral horns analyzed per age) to age-matched WTs $(\mathrm{n}=2-4 \mathrm{WT}$ animals/15-50 ventral horns per age). The number of NeuN-IR motor neurons was significantly decreased in 3 and 4 month old Sod $1^{G 93 A}$ mutants by $77 \%$ and $63 \%$ of the WT number, respectively (figure $1 \mathrm{~h}, \mathrm{p}<0.001$, Bonferroni-corrected pair comparisons). These decreases coincided with the onset of muscle weakness and are larger than cell losses estimated in previous studies (maximum $50 \%$ cell loss at end-stage $\operatorname{Sod} 1^{G 93 A}$ mice) using choline acetyltransferase (ChAT) immunoreactivity or Nissl stains to identify surviving motor neurons (Chiu et al., 1995). This difference could be explained by the inclusion in the ChAT and Nissl counts of the relatively more ALS-resistant $\gamma$-motor neurons. However, the number of NeuN-IR profiles was similarly decreased in 3 and 4 month old animals despite the known progression of motor neuron cell death that occurs during this period. Thus, the most parsimonious interpretation is that NeuN is downregulated in motor neurons prior to ChAT and cell death. To provide support for this explanation we analyzed NeuNimmunofluorescence in ChAT-IR motor neurons of three 3-month-old $\operatorname{Sod} 1^{G 93 A}$ mice and compared them with three age-matched WTs. We analyzed four ventral horn sections (50 $\mu \mathrm{m}$ thickness) of the lumbar 4 segment in each animal. On average $36.7 \pm 1.9$ ( \pm S.D.) ChAT-IR motor neurons were counted per ventral horn in WTs and 25.0 4.7 ( \pm S.D.) in Sod1 ${ }^{G 93 A}$ mice. This represents a $32 \%$ depletion in ChAT-IR motor neurons $(\mathrm{p}<0.05, \mathrm{t}=$ test, $\mathrm{n}=3$ animals), which is similar to what has been reported in the literature at this age(Chiu et al., 1995). It is also a smaller depletion than estimated from NeuN-IR motor neurons. To analyze NeuN-immunofluorescence in ChAT-IR motor neurons we used $478 \mu \mathrm{m}^{2}$ as cut-off cross-sectional area to distinguish between aand $\gamma$-motor neurons (see Shneider et al., 2009). In both WT and Sod1 ${ }^{G 93 A}$ mice, average NeuN-immunofluorescence in ChAT-IR motor neurons corresponding to a $\gamma$-size was significantly less than in amotor neurons. In addition, average NeuN-immunofluorescence in $\gamma$-or a-motor neurons was significantly less in $\operatorname{Sod} 1^{G 93 A}$ mice compared to WTs $(52.9 \pm 1.9( \pm$ S.E.M. $)$ intensity units (IU) and $35.2 \pm$ $2.1 \mathrm{IU}$ on 8 bit images of $\gamma$-motor neurons in respectively WT and $\operatorname{Sod} 1^{G 93 A}$ mice compared to $160.2 \pm 0.7$ IU and $115.2 \pm 2.1 \mathrm{IU}$ in $\mathrm{a}$-motor neurons; $\mathrm{n}=3$ animals per group and all groups significantly different from each other: $\mathrm{p}<0.001$ One-way ANOVA followed by post-hoc Bonferroni T-tests). Moreover, 31.1\% WTChAT-IR a-motor neurons had NeuN immunofluorescence intensities at very low or background level (<60 IUs, i.e., approximately twice the average background level in grey matter). These cells had sizes corresponding to the $\gamma$-population. The percentage of ChAT-IR motor neurons with this low level of NeuN immunofluorescence increased to $50.6 \%$ in 3 month $\operatorname{Sod} 1^{G 93 A}$ mice and these included a proportion of the larger motor neurons. Conversely the percentage of ChAT-IR motor neurons with high levels of NeuN-immunofluorescence (>150 IUs) decreased from $45.9 \%$ in the WT to $23.5 \%$ in $\operatorname{Sod} 1^{G 93 A}$ mice. Taken together, these data show that in three-month-old $\operatorname{Sod} 1^{G 93 A}$ mice NeuN immunoreactivity is strongly downregulated in ChAT-IR motor neurons.

Significant decreases in the number of LIX large NeuN-IR profiles were also detected in WTs between 1.5 and 2 months and between 3 and 4 months of age (not indicated in figure). These decreases are unlikely to be caused by age-dependent NeuN downregulation. If this was the case, the percentage of ChAT-IR motor neurons lacking NeuN-IR should have increased. However, this percentage did not significantly change in WT animals of different age: $30.7 \%$ at 1 month ( $\mathrm{n}=2$ animals), $30.2 \%$ at 2 months $(\mathrm{n}=1$ animal), $32.1 \%$ at 3 months ( $n=4$ animals) and $31.8 \%$ at 4 months ( $n=2$ animals). These percentages correspond well with the size of the population of NeuN-negative $\gamma$-motor neurons estimated in similar lower lumbar segments (Shneider et al., 2009). Since there is no evidence for motor neuron cell death in normal animals of this age, the most likely explanation is that reductions in motor 
neuron profiles per section are due to a lowering of cellular density because increases of spinal cord size, length and cross-sectional area both increased with age.

\section{Most calbindin-IR Renshaw cells survive even at late stages of the disease}

Calbindin-IR Renshaw cells were easily identifiable by their unique location in ventral LVII and LIX and their characteristic morphology (figures 1b,d,e,f,g; see Alvarez and Fyffe, 2007 for discussion of identification criteria). Their location and overall morphology did not change with age or in $\operatorname{Sodl}^{G 93 A}$ animals. Similar to NeuN-IR motor neurons there was a significant 38\% decrease in calbindin-IR Renshaw cell number in WTs from 1 to 4 months $(\mathrm{p}<0.001$ ANOVA). We detected on average $8.7 \pm 0.3$ cells per ventral horn section $(50 \mu \mathrm{m}$ thick) at 1 month (range 7.4 to 10.2 cells in $n=4$ animals, total 89 ventral horn analyzed) and $5.4 \pm 0.2$ at 4 months ( $\mathrm{n}=2$ animals, 105 ventral horns) $(\mathrm{p}<0.05$; Bonferroni-corrected pair comparisons). No significant difference in the number of calbindin-IR Renshaw cells was detected in $\operatorname{Sod} 1^{G 93 A}$ mice compared to the average of their respective age-matched WTs until 4 months of age, when we detected a $29 \%$ depletion with respect to WT numbers (figure 1i; $\mathrm{p}<0.05$; post-hoc Bonferroni-corrected pair comparisons).

To investigate whether other interneurons were similarly affected, we analyzed all NeuN-IR interneuronal profiles in the ventral horn. The ventral horn was defined as the region below a horizontal line drawn from the dorsal tip of the central canal. We counted interneuronal profiles as small NeuN-IR neurons (diameter $<30 \mu \mathrm{m}$ ) with a prominent nucleolus. For these counts we analyzed 4 ventral horns per animal and 2 animals per genotype/age. We observed that the interneuron profiles per section also decreased by $30 \%$ in WT animals from 1 to 4 months. Similar to Renshaw cells, no difference between $\operatorname{Sod} 1^{G 93 A}$ animals and age-matched WTs was observed until 4 months of age (figure $1 \mathrm{j}$ ), at which point there was a significant $37 \%$ decrease in the number of ventral horn NeuN positive interneurons $(p<0.05$; Bonferroni-corrected pair comparisons). This conclusion is consistent with a recent survey of inhibitory interneurons suggesting that large losses of these cells occur in this animal model only after motor neuron degeneration (Hossaini et al., 2011).

\section{Renshaw cell markers calbindin and chrna2 respond differently during ALS progression}

To further evaluate the status of Renshaw cells during ALS progression, we analyzed the expression of calbindin and the a 2 subunit of nicotinic receptor (chrna2) mRNAs in Renshaw cells and compared them to calbindin-IR. Dual in situ hybridization (ISH) and immunohistochemistry (IHC) for calbindin mRNA and protein (figure 2a-f) and ISH for chrna2 (figure $2 \mathrm{~g}-1$ ) were performed on lumbar spinal cord sections from $\operatorname{Sod} 1^{G 93 A}$ mice at days 40, 60, 80, 100 and at end stage (120-150 days). In this case, we pooled data from 2 to 6 animals ( $\mathrm{n}=18-185$ sections per age) and compared them to WT animals age-matched to end-stage (120-150 days). As expected from the results described above, ISH and IHC demonstrated a slow decline in the number of calbindin-positive cells that reached significance by end stage ( $\mathrm{p}<0.001$ in both cases, one-way ANOVA, post-hoc Bonferroni tests). However, there were also some differences between both methods. At end-stage, the number of calbindin mRNA expressing cells was significantly lower (85\% decrease compared to WT) than that of calbindin-IR neurons ( $36 \%$ decrease) $(\mathrm{p}<0.01)$ (figure $2 \mathrm{~m}-\mathrm{n}$ ). Downregulation of calbindin gene expression might therefore precede downregulation of calbindin protein levels. Increased stability of calbindin protein with respect to its mRNA might be responsible for the significant lag time between the decrease of mRNA and protein, as detected by our techniques. Differences in sensitivity and signal saturation between the two methods could further amplify these differences.

Interestingly, the decline in the number of chrna2 mRNA positive cells in the Renshaw cell area occurred earlier. Significant differences relative to WTs were detected at day 80 and 
continued to decrease through day 100 all the way to end stage ( $p<0.001$ in all cases, oneway ANOVA, post-hoc Bonferroni tests) (figures $2 \mathrm{~g}-1$ and $\mathrm{o}$ ). The early downregulation of chrna2 in Renshaw cells suggests functional alterations in synaptic transmission between motor axons and Renshaw cells before what would be predicted by calbindin-expression. To further investigate the overlap between the two markers, we performed a double IHC (calbindin) and ISH (chrna2) on WT and end stage $\operatorname{Sod} 1^{G 93 A}$ mice (figures 2p-q). In WTs, the number of chrna2 positive cells and calbindin-IR cells was similar and $90 \%$ of the total number of Renshaw cells examined expressed both markers. In contrast, in end stage mice only $25 \%$ of the Renshaw cell population expressed both calbindin and chrna2 ( $\mathrm{p}<0.001$, ttests, figure 2r). Moreover ,the number of calbindin-IR cells decreased by $42 \%$ in end stage Sod $1^{G 93 A}$ mice compared to age-matched WTs, while chrna2 positive cells decreased $77 \%$ ( $\mathrm{p}<0.001$, one-way ANOVA and post-hoc Bonferroni tests; figure $2 \mathrm{r}$ show changes in these populations by the relative sizes of the circles).

\section{VAChT expression is reduced in motor neurons in parallel with decreased chrna2 expression in Renshaw cells}

The previous analyses suggest a relatively early loss of nicotinic receptivity in Renshaw cells. To investigate whether this change was paralleled by downregulation of vesicle acetylcholine transporter (VAChT) expression in the presynaptic side, we performed ISH for $V A C h T$ in the spinal cords of $\operatorname{Sod} 1^{G 93 A}$ mice of 40,60, 80, 100 days of age and at end stage and compared them to WT animals as before (data pooled from $\mathrm{n}=4-6$ mice at each time point and 4-14 sections from each animal were analyzed). The number of VAChT positive cells was decreased at day 80, day 100 and at end stage compared to WT (all $\mathrm{p}<0.001$ ) (figure 3a-f and s). This time course is similar to the decreases observed in nicotinic receptors in the postsynaptic Renshaw cell and suggests an association with synaptic retraction and axonopathy. Axonal degeneration has been described at the NMJ and in the medial gastrocnemius muscle (a lower lumbar motor pool that resides in similar segments to those used in our analyses), synaptic retraction is initiated at P50 and is very extensive at P80 (Frey et al., 2000).

\section{The fast motor neuron markers Calca and Chodl are affected differently as the disease progresses}

Peripherally, motor axons arising from fast motor units are affected in the $\operatorname{Sod} 1^{G 93 A}$ mutant mouse before slow motor units (Pun et al., 2006; Saxena et 2009) and centrally, fast motor units make more synapses in the Renshaw cell area (at least in the cat: Cullheim and Kellerth, 1978). Therefore, in the same sample used for $V A C h T$ analysis, we analyzed expression of Calca and Chondrolectin (Chodl), two genes specifically expressed in fast motor units (Enjin et al 2010). We have previously shown that these markers are affected differently at disease end stage in the Sod1 ${ }^{G 93 A}$ mouse (Wootz et al 2010). To further investigate the time course of the earliest changes we performed ISH for these markers at different time points. Each marker was altered with a different time course. The number of Calca positive cells was decreased at day $100(\mathrm{p}<0.05)$ and at end stage $(\mathrm{p}<0.001)$ compared to WT (figure $3 \mathrm{~g}-1$ and t), while the number of Chodl positive cells progressively decreased from day 80 to day 100, and none were found at end stage (figure $3 \mathrm{~m}-\mathrm{r}$ and $\mathrm{u})(\mathrm{p}<0.001$, one-way ANOVA, post-hoc Bonferroni tests). Thus, we conclude that different mRNA species expressed in fast motor neurons respond differently to the disease. The data also demonstrates that changes in gene expression in fast motor neurons are initiated relatively early.

\section{VAChT-IR contacts on Renshaw cells are abnormal at early stages of ALS}

The results described above suggest parallel changes in pre-and postsynaptic genes involved at the synapses between motor neurons and Renshaw cells. To analyze directly these 
synapses, we performed dual immunofluorescent preparations between VAChT and calbindin (figure 4a-f). VAChT- IR bouton contacts on WT calbindin-IR Renshaw cells preferentially target dendrites (Alvarez et. al., 1999; Siembab et al., 2010). In WT animals, VAChT-IR boutons on Renshaw cell dendrites were of medium size (usually between 1 and $4 \mu \mathrm{m}$ in average diameter) and contained similar strong and relatively uniform VAChTimmunolabeling (figure $4 \mathrm{~b}$ ). The linear density of VAChT-IR boutons (number of boutons per $100 \mu \mathrm{m}$ of linear dendrite) on WT Renshaw cell dendrites was not significantly different in 1, 2, 3 and 4 month old animals(n=11 to 15 Renshaw cells sampled from 2 animals per age and reconstructed using Neurolucida). In 3 and 4 month old Sod1 ${ }^{G 93 A}$ mice they were however significantly decreased compared to their age-matched controls (figure $4 \mathrm{c}-\mathrm{f} ; \mathrm{n}$ p $<0.05$ Bonferroni corrected t-tests; 11-28 reconstructed Renshaw cells form 2-4 Sod1 ${ }^{G 93 A}$ animals per age) or to a pooled WT average ( $\mathrm{n}=51$ WT Renshaw cells from 8 animals, 2 per age, not shown; $\mathrm{p}<0.05$ post-hoc Bonferroni tests). Overall, a $62 \%$ reduction in synaptic density was found at 3 months and $74 \%$ at 4 months. Moreover, around $20 \%$ of 4 month Sod1 ${ }^{G 93 A}$ Renshaw cells ( $\mathrm{n}=28$ cells in 4 mice) were completely denervated in the analyzed dendrite regions (see methods). Renshaw cells in 2-month-old Sod1 ${ }^{G 93 A}$ animals were also partially depleted of VAChT-IR synapses compared to WT but the difference did not reach significance in our samples(n=11 WT and 12 Sod1 ${ }^{\text {G93A; }} \mathrm{p}=0.23 \mathrm{t}$-test). Similar results were observed when comparing surface densities (number of boutons per $100 \mu \mathrm{m}^{2}$ of dendrite surface, not shown). Despite the lack of quantitative differences in VAChT-IR contact density in 2-month-old Sod1 ${ }^{G 93 A}$ mice, morphological alterations were evident. VAChT-IR boutons in contact with Renshaw cells usually had a ring-like appearance with less or no immunoreactivity in the center of the bouton. At two months, there were an abundance of such altered VAChT-IR varicosities (figure 4d) while later, a large percentage of the remaining varicosities appear more normal in shape and distribution of immunoreactivity (figure 4e).

\section{Ultrastructural alterations of VAChT immunoreactive motor axons in Sod1 ${ }^{\text {G93A }}$ mice $^{\text {. }}$}

An ultrastructural study was carried out in 2.5 month old $\operatorname{Sod} 1^{G 93 A}$ mice to better define the nature of synaptic abnormalities at this age. For electron microscopy, motor axon VAChTIR synaptic boutons were identified in WTs as those making synapses on Renshaw cell calbindin-IR dendrites. These boutons displayed normal morphologies and contained VAChT-IR synaptic vesicles clustered in the presynaptic active zone and distributed also throughout the center of the boutons (figure 5a). Motor axon VAChT-IR boutons in the Renshaw cell regions of $\operatorname{Sod} 1^{G 93 A}$ mice were identified by the presence of abnormal mitochondria. By difference to WT synapses they frequently displayed most VAChT-IR in the periphery of the terminals (figure 5b-e). VAChT-IR displacement was due to space occupying abnormal mitochondria, degenerative structures or neurofilament accumulations in the center of synaptic boutons(figures 5b-d). However, other times a preferential association of VAChT-immunoreactivity with the plasma membrane was found even in absence of center occupying abnormal structures in varicosities that either established synapses (figure 5e) or lacked synaptic active zone regions (figure 5f). This suggests the possibility of excess non-recycled synaptic vesicle membrane and VAChT protein in the plasma membrane. Finally, clumping of VAChT-IR synaptic vesicles was also visible in some structures that seem to correspond with preterminal axonal segments (figure $5 \mathrm{~g}$ ). VAChT-IR C-terminals on motor neurons (of inter neuronal origin) contained normal mitochondria and did not show similar structural abnormalities in their boutons (figure $5 \mathrm{~h}$ ), suggesting that the observed alterations are specific to VAChT-IR cholinergic motor axons.

In summary, significant synaptic pathology was observed in motor axon synapses on Renshaw cells at 2.5 months of age in parallel with changes in expression of genes encoding for presynaptic transporters ( $V A C h T$ ) and postsynaptic receptors (chrna2). 


\section{Changes in calbindin-immunoreactive axons in lamina IX motor pools}

To investigate whether changes in the synapses from Renshaw cells to motor neurons also occur during disease progression we analyzed the density of calbindin-IR contacts on motor neurons. Ventral horn calbindin-IR axons mainly arise from Renshaw cells as demonstrated through genetic labeling (Sapir et al., 2004; Siembab et al., 2010). Analyses were carried out on ChAT-IR motor neurons (figure 6a-e) and on NeuN-IR motor neurons (figure 6f-i). We confirmed that all calbindin-IR varicosities in contact with the motor neuron surface in WT and $\operatorname{Sod} 1{ }^{G 93 A}$ mice were synapses by immunodetection of bassoon, a presynaptic active zone protein. In two previous analyses, we also confirmed that the majority of calbindin-IR varicosities in contact with motor neuron somata are inhibitory and contain presynaptic VIAAT (unpublished, Michael Kraspulski and FJA) or postsynaptic gehyrin (Sapir et al., 2004). In the lumbar enlargement, Renshaw cell axon projections have a dorsolateral orientation, being very dense around the most ventral motor pools of the lateral motor column (LMC) and in the medial motor column (MMC).Renshaw cell axon density decreases around motor neurons located in more dorsal LMC pools. This distribution of Renshaw cell axons parallels the known distribution of recurrent inhibition strength, being reduced or nonexistent in the more dorsally located pools corresponding to toe flexors and plantar muscles (Trank et al., 1999). Therefore we focused the analyses on motor neurons located in the lower half of LIX. Even after constraining the sample locations, we found pronounced variability in contact densities even within WT motor neurons; thusquantitative data is presented to illustrate this variability (figures 6e,i). On ChAT-IR motor neurons in 3 month $\operatorname{Sod} 1^{G 93 A}$ mice, we found a significant increase in the density of calbindin-IR synaptic contacts (i.e., positive for bassoon) compared to WTs (figure 6e; WT: $1.5 \pm 0.2$ \pm SEM synaptic contacts per $100 \mu \mathrm{m}$ of membrane perimeter in approximately $0.7 \mu \mathrm{m}$ thin confocal optical sections; Sod1 ${ }^{G 93 A}: 2.0 \pm 0.1$ synaptic contacts; $\mathrm{p}<0.001$, t-test; $\mathrm{n}=36$ Sod $1^{G 93 A}$ and 36 WT motor neurons; 12 motor neurons per animalin each of three animals per group). All calbindin-IR varicosities in contact with the motor neurons surfaces contained bassoon immunoreactivity. Thus, Renshaw cell synapses on motor neurons seemed to increase at three months of age.

Using NeuN immunoreactivity, we further clarified the nature and time course of these changes. Areas with reduced numbers of NeuN-IR motor neurons show decreased density of calbindin-IR axons and remaining axons seem focused around the NeuN-IR motor neurons that are left (arrows in figure 6f). To elucidate the time course of this change, LIX NeuN-IR motor neurons we reanalyzed at four different ages ( $\mathrm{n}=19$ to 24 motor neurons sampled in two animals per age and genotype). Sod1 ${ }^{G 93 A}$ motor neurons in 1-month-old animals were similar to WTs, both in average density and variability among cells. In contrast, 2 and 3 months old animals displayed on average a larger contact density $(\mathrm{p}<0.01$, t-tests; $0.88 \pm$ 0.11 contacts $/ 100 \mu \mathrm{m}$ in 2 month WT and $1.51 \pm 0.18$ in $\operatorname{Sod} 1^{G 93 A} ; 1.22 \pm 0.16$ contacts/ $100 \mu \mathrm{m}$ in 3 month WT and $2.70 \pm 0.33$ in $\operatorname{Sod} 1^{G 93 A}$ ) and also higher standard deviations from the average. Finally, in 4 months $\operatorname{Sod} 1^{G 93 A}$ animals contact densities and distributions returned to be similar to WTs.

From these data we conclude that Renshaw cell calbindin-IR axons are lost from regions of lamina IX that have extensively lost NeuN-IR motor neurons and undergo compensatory sprouting on remaining NeuN-IR motor neurons starting at 2 months of age and peaking at 3 months. Finally, at end-stage, remaining motor neurons lose this excess of Renshaw cell innervation.

\section{Discussion}

Here we report that disease onset in the $\operatorname{Sod} 1^{G 93 A}$ mice coincides with a decrease in the number of motor neurons expressing NeuN protein as well as VAChT and Chodl mRNA 
and that these changes correlate with motor synapse disconnection. In parallel, we found that intraspinal motor axon synaptic terminals become structurally disorganized and simultaneously, Renshaw cells downregulate nicotinic receptor expression. This synaptic disorganization is followed by a retraction of motor synapses from Renshaw cells (figure 7), suggesting that motor synapse loss is a consequence of earlier synaptic failure. The results therefore suggest that the reduced recurrent inhibition demonstrated in ALS patients, studied after an average of 23 months disease duration (Raynor and Shefner, 1994), is likely the result of an earlier disorganization of intraspinal motor axon synapses. These alterations likely disconnect the recurrent inhibitory circuit just before disease onset and could result in deficient control of motor neuron firing. This deficit might exacerbate the known hyperexcitability of motor neurons, which can be demonstrated from early development in several ALS murine models, and contribute to trigger the onset of disease by removing an important feedback control of motor neuron activity.

\section{Do Renshaw cells die early in ALS?}

Our results agree with studies that suggest that Renshaw cells are largely unaffected in presymptomatic animals and that most survive, even at end-stages of the disease(Morrison et al., 1996, Knirsch et al., 2001; Chang and Martin, 2009). Late interneuron loss that do not precede motor neuron death agrees with analyses of postmortem ALS tissue (Stephens et al., 2006) as well as with a more recent study concluding that spinal inhibitory interneuron pathology follows motor neuron degeneration in ALS murine models (Hossaini et al., 2011). Despite the high firing competence of Renshaw cells, it is unlikely that an energy deficit makes them vulnerable. Mitochondria in dendrites postsynaptic to motor axon synapses in 2.5 months $\operatorname{Sod} 1^{G 93 A}$ animals show normal ultrastructural morphology suggesting that Renshaw cells are not affected by the same mitochondrial dysfunction found in motor neurons. Moreover, Renshaw cells express both calbindin and parvalbumin (Alvarez et al., 2005), and consequently have a large calcium buffering capacity shown to protect cells in ALS (Roy et al, 1998; Beers et al., 2001). In addition, our work suggests that interpreting loss of marker expression as cell losses should be done with great caution, since surviving cells might downregulate or alter gene expression during disease progression independent of cell death. Therefore, whether a proportion of Renshaw cells eventually die during the disease cannot be definitively answered until new animal models are developed in which Renshaw cells are permanently marked before disease onset and their exact numbers assessed independent of marker/gene expression. However, we can conclude that the majority of Renshaw cells survive and reject the recent proposition that "loss of Renshaw cells occurs before and more severely than motor neuron loss" (Fornai et al., 2008; Pasquali et al., 2009). In conclusion, the alteration of motor neuron recurrent inhibition in ALS is likely due to synaptic pathology and not to interneuron cell death.

\section{Areinhibitory synapses from Renshaw cells onto motor neurons decreased?}

Inhibitory synapses on spinal motor neurons were initially proposed to be preferentially spared until end-stage in the $\operatorname{Sod} 1^{G 93 A}$ model and cause over-inhibition in presymptomatic and early symptomatic animals (Schutz, 2005). Later studies proposed that inhibitory synapses started to disassemble earlier, resulting in a transient period around disease onset with decreased inhibitory to excitatory ratios (Pullen and Athanasiou, 2009; Sunicoet al., 2011). These changes seem to affect mainly glycinergic synapses, while GABAergic synapses were relatively unchanged (Chang and Martin, 2009, 2011). The later results were interpreted as evidence for decreased inhibition and a deficit in Renshaw cell output. Renshaw cell synapses are, however, both glycinergic and GABAergic (Cullheim and Kellerth, 1981; Schneider and Fyffe, 1992)and inhibitory inputs onto motor neurons originate from a large number of sources. It is therefore problematical to extrapolate from a partial decrease in inhibitory synaptic coverage to specific deficits in Renshaw cell synapses. 
We analyzed innervation from calbindin-IR axons to quantify Renshaw cell synapses and this led us to a different conclusion. Calbindin-IR synapses on $\operatorname{Sod} 1^{G 93 A}$ motor neurons were not reduced, but in fact a transitory sprouting of Renshaw cell synapses occurred at 2 and 3 months of age, and preferentially targeted motor neurons retaining NeuNimmunoreactivity. Chang and Martin (2009) also reported a transient upregulation of glycinergic synapses on motor neuronsaround 10 weeks of age in the same early onset Sod $1^{G 93 A}$ model. It remains a possibility that Renshaw cell inputs are reduced in degenerating NeuN-negative motor neurons and a reduction of targets could explain calbindin-IR axon sprouting on remaining viable motor neurons. This would explain the different levels of increase detected in NeuN-IR motor neurons compared to the whole population of ChAT-IR motor neurons at 3 months of age. Nonetheless, we can conclude that Renshaw cell synapses are not withdrawn from presymptomatic motor neurons, or from motor neurons that continue to express NeuN after disease onset.

Our anatomical results cannot address, however, whether these synapses are functionally compromised. Reductions in glycine receptor (GlyR) binding sites are correlated with the degree of motor neuron loss in ALS patients (Hayashi et al., 1981; Whitehouse et al., 1983). Similarly, synaptic and non-synaptic glycinergic currents as well as GlyRa1 subunit expression were decreased in cultures of $\operatorname{Sod} 1^{G 93 A}$ embryonic motor neurons (Chang and Martin, 2011). In contrast, studies in presymptomatic hypoglossal motor neurons in perinatal pups (P4-P10) suggested that spontaneous inhibitory synaptic events increased their frequency with a tendency towards higher, not lower, amplitudes (vanZundert et al., 2008). There is however good agreement in that $\mathrm{GABA}_{\mathrm{A}}$ receptor subunit expression and $\mathrm{GABA}_{\mathrm{A}}{ }^{-}$ dependent currents are unaltered in $\operatorname{Sod} 1^{G 93 A}$ motor neurons (Petri et al., 2005; Chang and Martin, 2011). Thus, although direct recordings will be necessary, it is expected that at least the GABAergic components of the Renshaw cell synapse will be relatively unaltered and given the large contribution of the GABAergic current to the net synaptic current in mixed glycine/GABA synapses it is possible that these synapses retain a significant amount of inhibitory capacity (Russier et al., 2002; Gonzalez-Forero and Alvarez, 2005). Inputs from several sources can drive activity in Renshaw cells (reviewed in Dougherty and Kiehn, 2010), therefore, Renshaw cell synapses could sustain significant inhibitory actions when recruited by inputs other than motor axons. However, recurrent inhibition would be lost because of the deficitin motor axon synapses.

\section{Deficits in motor axon synapses disconnect the recurrent inhibitory circuit}

A major finding in our results was the anomalous motor axon synapses on Renshaw cells. This was substantiated by structural synaptic disorganization, decreased presynaptic $V A C h T$ and postsynaptic nicotinic receptor (chrna2) expression and thereafter the loss of $60-75 \%$ of synapses and complete motor axon denervation of some Renshaw cells. Our results agree with the hypothesis that the initial stages of ALSare characterized by motor axon synaptic failure and axonopathy. This hypothesis is based was first proposed after observations at the peripheral neuromuscular junction (NMJ) (Pinter et al., 1995; Frey et al., 2000; Fischer et al., 2004; Schaefer et al., 2005; Pun et al., 2006). Here we suggest that similar changes occur in the intraspinal collaterals of the same axons. Motor axon retraction at the NMJ occurs in two phases in the early onset $\operatorname{Sod} 1^{G 93}$ mice model. Hind limb triceps surae NMJs first become dennervated between postnatal days 48 and 55, some being reoccupied around day 60 and finally permanently dennervated between days 80 and 90 (Frey et al., 2000; Pun et al., 2006). Muscles innervated by fast motor units exhibited earlier pathology than slow motor units, and collateral sprouting from slow motor axons transiently reoccupied vacated NMJs (Schaefer et al., 2005; Pun et al., 2006; Hegedus et al., 2008). This reflects the differential time course of disease manifestation in vulnerable "fast" motor neurons vs. resistant "slow" motor neurons (Saxena el al., 2009) and suggests the possibility of similar 
compensations on Renshaw cells at 2 months of age during the first manifestations of synaptic disease. As in the NMJ, a permanent and significant dennervation occurred at 3 months of age. The similar time courses suggest that motor axon pathology occurs globally and almost simultaneously in the peripheral and central synaptic terminals. Interestingly, the largest density of synaptic boutons in the Renshaw cell area originates from the vulnerable fast motor units (Cullheim and Kellerth, 1978) and changes in gene expression in fast motor neurons (Chodl) occurred in concert with the onset of synaptic disorganization.

Calca mRNA was relatively more stable in fast motoneurons. The reason for the comparatively more stable expression is unknown but it is interesting to note that one of the encoded proteins is katacalcin, a calcium-lowering peptide involved in calcium regulation, similar to calbindin in Renshaw cells. This suggest the possibility that genes and proteins involved in synaptic transmission at the motor axon synapse are affected relatively early while calcium regulating genes are affected relatively late in the disease within both individual motor neurons and Renshaw cells.

\section{Is it relevant to pathology?}

ALS is a multifactorial neurodegenerative disease in which several mechanisms converge to increase motor neuron stress until a threshold level triggers disease and cellular pathology (reviewed in Saxena and Caroni, 2011, van Zundert et al., 2012). Recurrent inhibition limits and stabilizes motor neuron firing in response to excitatory inputs (Noga et al., 1987; Hamm, 1990; Williams and Baker, 2009) and this function is carried out dynamically such that inhibitory feedback is adjusted in a task specific manner (Hultborn et al., 1979; 2004). Lack of recurrent inhibition would imply decreased feedback control of motor neuron firing and this could exacerbate the hyperexcitability of motor neurons recently described in several ALS murine models (Kuo et al., 2004, 2005, 2006; van Zundert et al., 2008; PamboPambo et al., 2009; Quinlan et al., 2011). However, the net effect of recurrent inhibition in ALS was recently questioned based on the fact that Renshaw cell synapses target motor neuron dendrites and elicit relatively small effective currents at the soma (Mazzocchio and Rossi, 2010). Indeed, Renshaw cell modulation of motor neuron firing evoked by injected currents at the soma is not very effective while motorneurons modulate firing in their steady-state basal primary range (Lindsay and Binder, 1991). However, Renshaw cell inhibition would be more effective counteracting mechanisms that increase motor neuron firing in ALS.

Two key mechanisms that enhance firing in ALS motor neurons is the early maturation of $\mathrm{Na}^{+}$and $\mathrm{Ca}^{2+}$ persistent inward currents (PICs) (Kuo et al., 2004, 2005; van Zundert et al., 2008; Pambo-Pambo et al., 2009; Meehan et al., 2010; Quinlan et al., 2011) and higher than normal excitatory synaptic activity (van Zundert et al., 2008). This could be in part the result of hyperexcitable spinal circuits, since increased excitability has been found also on interneurons and at the network level (van Zundert et al., 2008; Jiang et al., 2009). Increased PICs would further potentiate excitatory inputs on motor neuron dendrites (Heckman et al., 2008 ) and lead to excitotoxicity because excessive $\mathrm{Ca}^{2+}$ entry that is inadequately buffered (reviewed in Quinlan, 2011; van Zundert et al., 2012). Renshaw cell inhibitory synapses are optimally positioned to both deactivate PICs and modulate excitatory inputs on motor neuron dendrites (Bui et al., 2008). Therefore the net effect of recurrent inhibition is particularly strong in physiological states with enhanced PIC-dependent depolarization (Venugopal et al., 2011). Thus, while recurrent inhibition elicited firing reductions of 1 or 2 impulses per second when motor neurons are kept at their basal steady-state primary firing range, this decrement is at least one order of magnitude more effective when motor neuron firing is evoked by natural synaptic inputs and PIC activation (Hultborn et al., 2003). Decreased recurrent feedback inhibition could therefore significantly intensify excessive PIC and synaptic activity contributing to create an hyperexcitable state that could lead 
toexcitotoxicity. Interestingly this occurs around, or just prior, the onset of the disease stage suggesting it might be a potentially important contributing factor that advances ALS towards motorneuron pathology.

\section{Supplementary Material}

Refer to Web version on PubMed Central for supplementary material.

\section{Acknowledgments}

We thank Dr. Neil Shneider for very helpful comments in this manuscript. Mr. Ricardo Zerda and James Webster did the electron microscopy processing.

Grant sponsors: This work was supported by grants from the NIHgrant NS NS047357 (FJA); The ALS Therapy Alliance-CVS Pharmacy (B.v.Z); Swedish Research Council - Medicine and Health; the foundations of Goran Gustafsson, A. Wiberg, Ahlen and Hedlund; Uppsala University; the Swedish Brain Foundation; and the Swedish Society for Medical Research (H.W.). K.K. is a Royal Swedish Academy of Sciences Research Fellow supported by agrant from the Knut and Alice Wallenberg Foundation.

\section{Literature Cited}

Altrock WD, tom Dieck S, Sokolov M, Meyer AC, Sigler A, Brakebusch C, Fassler R, Richter K, Boeckers TM, Potschka H, Brandt C, Loscher W, Grimberg D, Dresbach T, Hempelmann A, Hassan H, Balschun D, Frey JU, Brandstatter JH, Garner CC, Rosenmund C, Gundelfinger ED. Functional inactivation of a fraction of excitatory synapses in mice deficient for the active zone protein bassoon. Neuron. 2003; 37(5):787-800. [PubMed: 12628169]

Alvarez FJ, Dewey DE, McMillin P, Fyffe RE. Distribution of cholinergic contacts on Renshaw cells in the rat spinal cord: a light microscopic study. J Physiol. 1999; 515 ( Pt 3):787-797. [PubMed: 10066905]

Alvarez FJ, Fyffe RE. The continuing case for the Renshaw cell. J Physiol. 2007; 584(Pt 1):31-45. [PubMed: 17640932]

Alvarez FJ, Jonas PC, Sapir T, Hartley R, Berrocal MC, Geiman EJ, Todd AJ, Goulding M. Postnatal phenotype and localization of spinal cord V1 derived interneurons. J Comp Neurol. 2005; 493(2): 177-192. [PubMed: 16255029]

Alvarez FJ, Titus-Mitchell HE, Bullinger KL, Kraszpulski M, Nardelli P, Cope TC. Permanent central synaptic disconnection of proprioceptors after nerve injury and regeneration. I. Loss of VGLUT1/IA synapses on motoneurons. J Neurophysiol. 2011; 106(5):2450-2470. [PubMed: 21832035]

Beers DR, Ho BK, Siklos L, Alexianu ME, Mosier DR, Mohamed AH, Otsuka Y, Kozovska ME, McAlhany RE, Smith RG, Appel SH. Parvalbumin overexpression alters immune-mediated increases in intracellular calcium, and delays disease onset in a transgenic model of familial amyotrophic lateral sclerosis. J Neurochem. 2001; 79(3):499-509. [PubMed: 11701753]

Bezard E, Gross CE, Brotchie JM. Presymptomatic compensation in Parkinson's disease is not dopamine-mediated. Trends Neurosci. 2003; 26(4):215-221. [PubMed: 12689773]

Bui TV, Grande G, Rose PK. Relative location of inhibitory synapses and persistent inward currents determines the magnitude and mode of synaptic amplification in motoneurons. J Neurophysiol. 2008; 99(2):583-594. [PubMed: 18046006]

Chang Q, Martin LJ. Glycinergic innervation of motoneurons is deficient in amyotrophic lateral sclerosis mice: a quantitative confocal analysis. Am J Pathol. 2009; 174(2):574-585. [PubMed: 19116365]

Chang Q, Martin LJ. Glycine receptor channels in spinal motoneurons are abnormal in a transgenic mouse model of amyotrophic lateral sclerosis. J Neurosci. 2011; 31(8):2815-2827. [PubMed: 21414903]

Chiu AY, Zhai P, Dal Canto MC, Peters TM, Kwon YW, Prattis SM, Gurney ME. Age-dependent penetrance of disease in a transgenic mouse model of familial amyotrophic lateral sclerosis. Mol Cell Neurosci. 1995; 6(4):349-362. [PubMed: 8846004] 
Cleveland DW, Rothstein JD. From Charcot to Lou Gehrig: deciphering selective motor neuron death in ALS. Nat Rev Neurosci. 2001; 2(11):806-819. [PubMed: 11715057]

Coleman PD, Yao PJ. Synaptic slaughter in Alzheimer's disease. Neurobiol Aging. 2003; 24(8):10231027. [PubMed: 14643374]

Cullheim S, Kellerth JO. A morphological study of the axons and recurrent axon collaterals of cat alpha-motoneurones supplying different functional types of muscle unit. J Physiol. 1978; 281:301313. [PubMed: 702385]

Cullheim S, Kellerth JO. Two kinds of recurrent inhibition of cat spinal alpha-motoneurones as differentiated pharmacologically. J Physiol. 1981; 312:209-224. [PubMed: 7264991]

Dougherty KJ, Kiehn O. Functional organization of V2a-related locomotor circuits in the rodent spinal cord. Ann N Y Acad Sci. 2010; 1198:85-93. [PubMed: 20536923]

Eccles JC, Fatt P, Koketsu K. Cholinergic and inhibitory synapses in a pathway from motor-axon collaterals to motoneurones. J Physiol. 1954; 126(3):524-562. [PubMed: 13222354]

Enjin A, Rabe N, Nakanishi ST, Vallstedt A, Gezelius H, Memic F, Lind M, Hjalt T, Tourtellotte WG, Bruder C, Eichele G, Whelan PJ, Kullander K. Identification of novel spinal cholinergic genetic subtypes disclose Chodl and Pitx2 as markers for fast motor neurons and partition cells. J Comp Neurol. 2010; 518(12):2284-2304. [PubMed: 20437528]

Fischer LR, Culver DG, Tennant P, Davis AA, Wang M, Castellano-Sanchez A, Khan J, Polak MA, Glass JD. Amyotrophic lateral sclerosis is a distal axonopathy: evidence in mice and man. Exp Neurol. 2004; 185(2):232-240. [PubMed: 14736504]

Fornai F, Longone P, Cafaro L, Kastsiuchenka O, Ferrucci M, Manca ML, Lazzeri G, Spalloni A, Bellio N, Lenzi P, Modugno N, Siciliano G, Isidoro C, Murri L, Ruggieri S, Paparelli A. Lithium delays progression of amyotrophic lateral sclerosis. Proc Natl Acad Sci U S A. 2008; 105(6): 2052-2057. [PubMed: 18250315]

Frey D, Schneider C, Xu L, Borg J, Spooren W, Caroni P. Early and selective loss of neuromuscular synapse subtypes with low sprouting competencein motoneuron diseases. J Neurosci. 2000; 20(7): 2534-2542. [PubMed: 10729333]

Friese A, Kaltschmidt JA, Ladle DR, Sigrist M, Jessell TM, Arber S. Gamma and alpha motor neurons distinguished by expression of transcription factor Err3. Proc Natl Acad Sci U S A. 2009; 106(32): 13588-13593. [PubMed: 19651609]

Fyffe RE. Spatial distribution of recurrent inhibitory synapses on spinal motoneurons in the cat. J Neurophysiol. 1991; 65(5):1134-1149. [PubMed: 1869909]

Gonzalez-Forero D, Alvarez FJ. Differential postnatal maturation of GABAA, glycine receptor, and mixed synaptic currents in Renshaw cells and ventral spinal interneurons. J Neurosci. 2005; 25(8): 2010-2023. [PubMed: 15728841]

Graf RA, Kater SB. Inhibitory neuronal activity can compensate for adverse effects of beta-amyloid in hippocampal neurons. Brain Res. 1998; 786(1-2):115-121. [PubMed: 9554974]

Gurney ME, Pu H, Chiu AY, Dal Canto MC, Polchow CY, Alexander DD, Caliendo J, Hentati A, Kwon YW, Deng HX, et al. Motor neuron degeneration in mice that express a human $\mathrm{Cu}, \mathrm{Zn}$ superoxide dismutase mutation. Science. 1994; 264(5166):1772-1775. [PubMed: 8209258]

Hamm TM. Recurrentinhibition to and from motoneurons innervating the flexor digitorum and flexor hallucis longus muscles of the cat. J Neurophysiol. 1990; 63(3):395-403. [PubMed: 2329350]

Hayashi H, Suga M, Satake M, Tsubaki T. Reduced glycine receptor in the spinal cord in amyotrophic lateral sclerosis. Ann Neurol. 1981; 9(3):292-294. [PubMed: 6261674]

Heckman CJ, Hyngstrom AS, Johnson MD. Active properties of motoneurone dendrites: diffuse descending neuromodulation, focused local inhibition. J Physiol. 2008; 586(5):1225-1231. [PubMed: 17947305]

Hossaini M, Cano SC, van Dis V, Haasdijk ED, Hoogenraad CC, Holstege JC, Jaarsma D. Spinal inhibitory interneuron pathology follows motor neuron degeneration independent of glial mutant superoxide dismutase 1 expression in SOD1-ALS mice. J Neuropathol Exp Neurol. 2011; 70(8): 662-677. [PubMed: 21760539]

Hultborn H, Brownstone RB, Toth TI, Gossard JP. Key mechanisms for setting the input-output gain across the motoneuron pool. Prog Brain Res. 2004; 143:77-95. [PubMed: 14653153] 
Hultborn $\mathrm{H}$, Lindstrom S, Wigstrom H. On the function of recurrent inhibition in the spinal cord. Exp Brain Res. 1979; 37(2):399-403. [PubMed: 499395]

Ishii K, Wong JK, Sumikawa K. Comparison of alpha2 nicotinic acetylcholine receptor subunit mRNA expression in the central nervous system of rats and mice. J Comp Neurol. 2005; 493(2):241-260. [PubMed: 16255031]

Jiang M, Schuster JE, Fu R, Siddique T, Heckman CJ. Progressive changes in synaptic inputs to motoneurons in adult sacral spinal cord of a mouse model of amyotrophic lateral sclerosis. $\mathrm{J}$ Neurosci. 2009; 29(48):15031-15038. [PubMed: 19955354]

Kanning KC, Kaplan A, Henderson CE. Motor neuron diversity in development and disease. Annu Rev Neurosci. 2010; 33:409-440. [PubMed: 20367447]

Knirsch U, Sturm S, Reuter A, Bachus R, Gosztonyi G, Voelkel H, Ludolph AC. Calcineurin A and calbindin immunoreactivity in the spinal cord of G93A superoxide dismutase transgenic mice. Brain Res. 2001; 889(1-2):234-238. [PubMed: 11166710]

Kuo JJ, Lee RH, Zhang L, Heckman CJ. Essential role of the persistent sodium current in spike initiation during slowly rising inputs in mouse spinal neurones. J Physiol. 2006; 574(Pt 3):819834. [PubMed: 16728453]

Kuo JJ, Schonewille M, Siddique T, Schults AN, Fu R, Bar PR, Anelli R, Heckman CJ, Kroese AB. Hyperexcitability of cultured spinal motoneurons from presymptomatic ALS mice. J Neurophysiol. 2004; 91(1):571-575. [PubMed: 14523070]

Kuo JJ, Siddique T, Fu R, Heckman CJ. Increased persistent $\mathrm{Na}(+)$ current and its effect on excitability in motoneurones cultured from mutant SOD1 mice. J Physiol. 2005; 563(Pt 3):843854. [PubMed: 15649979]

Lindsay AD, Binder MD. Distribution of effective synaptic currents underlying recurrent inhibition in cat triceps surae motoneurons. J Neurophysiol. 1991; 65(2):168-177. [PubMed: 2016635]

Lorenzo LE, Barbe A, Portalier P, Fritschy JM, Bras H. Differential expression of GABAA and glycine receptors in ALS-resistant vs. ALS-vulnerable motoneurons: possible implications for selective vulnerability of motoneurons. Eur J Neurosci. 2006; 23(12):3161-3170. [PubMed: 16820006]

Mazzocchio R, Rossi A. Role of Renshaw cells in amyotrophic lateral sclerosis. Muscle Nerve. 41(4): 441-443. [PubMed: 20082418]

McPhail LT, McBride CB, McGraw J, Steeves JD, Tetzlaff W. Axotomy abolishes NeuN expression in facial but not rubrospinal neurons. Exp Neurol. 2004; 185(1):182-190. [PubMed: 14697329]

Meehan CF, Moldovan M, Marklund SL, Graffmo KS, Nielsen JB, Hultborn H. Intrinsic properties of lumbar motor neurones in the adult G127insTGGG superoxide dismutase-1 mutant mouse in vivo: evidence for increased persistent inward currents. Acta Physiol (Oxf). 2010; 200(4):361-376. [PubMed: 20874803]

Miana-Mena FJ, Munoz MJ, Yague G, Mendez M, Moreno M, Ciriza J, Zaragoza P, Osta R. Optimal methods to characterize the G93A mouse model of ALS. Amyotroph Lateral Scler Other Motor Neuron Disord. 2005; 6(1):55-62. [PubMed: 16036427]

Milnerwood AJ, Raymond LA. Early synaptic pathophysiology in neurodegeneration: insights from Huntington's disease. Trends Neurosci. 2010; 33(11):513-523. [PubMed: 20850189]

Morrison BM, Gordon JW, Ripps ME, Morrison JH. Quantitative immunocytochemical analysis of the spinal cord in G86R superoxide dismutase transgenic mice: neurochemical correlates of selective vulnerability. J Comp Neurol. 1996; 373(4):619-631. [PubMed: 8889947]

Nieto-Gonzalez JL, Moser J, Lauritzen M, Schmitt-John T, Jensen K. Reduced GABAergic inhibition explainscortical hyperexcitability in the wobbler mouse model of ALS. Cereb Cortex. 2011; 21(3): 625-635. [PubMed: 20643756]

Noga BR, Shefchyk SJ, Jamal J, Jordan LM. The role of Renshaw cells in locomotion: antagonism of their excitation from motor axon collaterals with intravenous mecamylamine. Exp Brain Res. 1987; 66(1):99-105. [PubMed: 3582539]

Palop JJ, Chin J, Bien-Ly N, Massaro C, Yeung BZ, Yu GQ, Mucke L. Vulnerability of dentate granule cells to disruption of arc expression in human amyloid precursor protein transgenic mice. $\mathrm{J}$ Neurosci. 2005; 25(42):9686-9693. [PubMed: 16237173] 
Palop JJ, Chin J, Mucke L. A network dysfunction perspective on neurodegenerative diseases. Nature. 2006; 443(7113):768-773. [PubMed: 17051202]

Pambo-Pambo A, Durand J, Gueritaud JP. Early excitability changes in lumbar motoneurons of transgenic SOD1G85R and SOD1G(93A-Low) mice. J Neurophysiol. 2009; 102(6):3627-3642. [PubMed: 19828728]

Pasquali L, Longone P, Isidoro C, Ruggieri S, Paparelli A, Fornai F. Autophagy, lithium, and amyotrophic lateral sclerosis. Muscle Nerve. 2009; 40(2):173-194. [PubMed: 19609902]

Petri S, Schmalbach S, Grosskreutz J, Krampfl K, Grothe C, Dengler R, Van Den Bosch L, Robberecht W, Bufler J. The cellular mRNA expression of GABA and glutamate receptors in spinal motor neurons of SOD1 mice. J Neurol Sci. 2005; 238(1-2):25-30. [PubMed: 16087196]

Pinter MJ, Waldeck RF, Wallace N, Cork LC. Motor unit behavior in canine motor neuron disease. J Neurosci. 1995; 15(5 Pt 1):3447-3457. [PubMed: 7751923]

Pullen AH, Athanasiou D. Increase in presynaptic territory of C-terminals on lumbar motoneurons of G93A SOD1 mice during disease progression. Eur J Neurosci. 2009; 29(3):551-561. [PubMed: 19187267]

Pun S, Santos AF, Saxena S, Xu L, Caroni P. Selective vulnerability and pruning of phasic motoneuron axons in motoneuron disease alleviated by CNTF. Nat Neurosci. 2006; 9(3):408-419. [PubMed: 16474388]

Quinlan KA. Links between electrophysiological and molecular pathology of amyotrophic lateral sclerosis. Integr Comp Biol. 51(6):913-925. [PubMed: 21989221]

Quinlan KA, Schuster JE, Fu R, Siddique T, Heckman CJ. Altered postnatal maturation of electrical properties in spinal motoneurons in a mouse model of amyotrophic lateral sclerosis. J Physiol. 2011; 589(Pt 9):2245-2260. [PubMed: 21486770]

Raynor EM, Shefner JM. Recurrent inhibition is decreased in patients with amyotrophic lateral sclerosis. Neurology. 1994; 44(11):2148-2153. [PubMed: 7969975]

Renshaw B. Central effects of centripetal impulses in axons of spinal ventral roots. J Neurophysiol. 1946; 9:191-204. [PubMed: 21028162]

Roy J, Minotti S, Dong L, Figlewicz DA, Durham HD. Glutamate potentiates the toxicity of mutant $\mathrm{Cu} / \mathrm{Zn}$-superoxide dismutase in motor neurons by postsynaptic calcium-dependent mechanisms. $\mathrm{J}$ Neurosci. 1998; 18(23):9673-9684. [PubMed: 9822728]

Russier M, Kopysova IL, Ankri N, Ferrand N, Debanne D. GABA and glycine co-release optimizes functional inhibition in rat brainstem motoneurons in vitro. J Physiol. 2002; 541(Pt 1):123-137. [PubMed: 12015425]

Sapir T, Geiman EJ, Wang Z, Velasquez T, Mitsui S, Yoshihara Y, Frank E, Alvarez FJ, Goulding M. Pax6 and engrailed 1 regulate two distinct aspects of renshaw cell development. J Neurosci. 2004; 24(5):1255-1264. [PubMed: 14762144]

Sasaki S, Warita H, Komori T, Murakami T, Abe K, Iwata M. Parvalbumin and calbindin D-28k immunoreactivity in transgenic mice with a G93A mutant SOD1 gene. Brain Res. 2006; 1083(1): 196-203. [PubMed: 16546142]

Saxena S, Cabuy E, Caroni P. A role for motoneuron subtype-selective ER stress in disease manifestations of FALS mice. Nat Neurosci. 2009; 12(5):627-636. [PubMed: 19330001]

Saxena S, Caroni P. Selectiveneuronal vulnerability in neurodegenerative diseases: from stressor thresholds to degeneration. Neuron. 2011; 71(1):35-48. [PubMed: 21745636]

Schaefer AM, Sanes JR, Lichtman JW. A compensatory subpopulation of motor neurons in a mouse model of amyotrophic lateral sclerosis. J Comp Neurol. 2005; 490(3):209-219. [PubMed: 16082680]

Schneider SP, Fyffe RE. Involvement of GABA and glycine in recurrent inhibition of spinal motoneurons. J Neurophysiol. 1992; 68(2):397-406. [PubMed: 1326603]

Schutz B. Imbalanced excitatory to inhibitory synaptic input precedes motor neuron degeneration in an animal model of amyotrophic lateral sclerosis. Neurobiol Dis. 2005; 20(1):131-140. [PubMed: 16137574]

Scott S, Kranz JE, Cole J, Lincecum JM, Thompson K, Kelly N, Bostrom A, Theodoss J, Al-Nakhala BM, Vieira FG, Ramasubbu J, Heywood JA. Design, power, andinterpretation of studies in the standard murine model of ALS. Amyotroph Lateral Scler. 2008; 9(1):4-15. [PubMed: 18273714] 
Shneider NA, Brown MN, Smith CA, Pickel J, Alvarez FJ. Gamma motor neurons express distinct genetic markers at birth and require muscle spindle-derivedGDNF for postnatal survival. Neural Dev. 2009; 4:42. [PubMed: 19954518]

Siembab VC, Smith CA, Zagoraiou L, Berrocal MC, Mentis GZ, Alvarez FJ. Target selection of proprioceptive and motor axon synapses on neonatal V1-derived Ia inhibitory interneurons and Renshaw cells. J Comp Neurol. 2010; 518(23):4675-4701. [PubMed: 20963823]

Spampanato J, Gu X, Yang XW, Mody I. Progressive synaptic pathology of motor cortical neurons in a BAC transgenic mouse model of Huntington's disease. Neuroscience. 2008; 157(3):606-620. [PubMed: 18854207]

Stephens B, Guiloff RJ, Navarrete R, Newman P, Nikhar N, Lewis P. Widespread loss of neuronal populations in the spinal ventral horn in sporadic motor neuron disease. A morphometric study. $\mathrm{J}$ Neurol Sci. 2006; 244(1-2):41-58. [PubMed: 16487542]

Sunico CR, Dominguez G, Garcia-Verdugo JM, Osta R, Montero F, Moreno-Lopez B. Reduction in the motoneuron inhibitory/excitatory synaptic ratio in an early-symptomatic mouse model of amyotrophic lateral sclerosis. Brain Pathol. 2011; 21(1):1-15. [PubMed: 20653686]

tom Dieck S, Sanmarti-Vila L, Langnaese K, Richter K, Kindler S, Soyke A, Wex H, Smalla KH, Kampf U, Franzer JT, Stumm M, Garner CC, Gundelfinger ED. Bassoon, a novel zinc-finger CAG/glutamine-repeat protein selectively localized at the active zone of presynaptic nerve terminals. J Cell Biol. 1998; 142(2):499-509. [PubMed: 9679147]

Trank TV, Turkin VV, Hamm TM. Organization of recurrent inhibition and facilitation in motoneuron pools innervating dorsiflexors of the cat hindlimb. Exp Brain Res. 1999; 125(3):344-352. [PubMed: 10229025]

Van Den Bosch L, Van Damme P, Bogaert E, Robberecht W. The role of excitotoxicity in the pathogenesis of amyotrophic lateral sclerosis. Biochim Biophys Acta. 2006; 1762(11-12):10681082. [PubMed: 16806844]

van Zundert B, Izaurieta P, Fritz E, Alvarez FJ. Early pathogenesis in the adult-onset neurodegenerative disease amyotrophic lateral sclerosis. J Cell Biochem. 2012 in press. [Epub ahead of print]. 10.1002/jcb.24234

van Zundert B, Peuscher MH, Hynynen M, Chen A, Neve RL, Brown RH Jr, Constantine-Paton M, Bellingham MC. Neonatal neuronal circuitry shows hyperexcitable disturbance in a mouse model of the adult-onset neurodegenerative disease amyotrophic lateral sclerosis. J Neurosci. 2008; 28(43):10864-10874. [PubMed: 18945894]

Venugopal S, Hamm TM, Crook SM, Jung R. Modulation of inhibitory strength and kinetics facilitates regulation of persistent inward currents and motoneuron excitability following spinal cord injury. $\mathrm{J}$ Neurophysiol. 2011; 106(5):2167-2179. [PubMed: 21775715]

Whitehouse PJ, Wamsley JK, Zarbin MA, Price DL, Tourtellotte WW, Kuhar MJ. Amyotrophic lateral sclerosis: alterations in neurotransmitter receptors. Ann Neurol. 1983; 14(1):8-16. [PubMed: 6137185]

Williams ER, Baker SN. Renshaw cell recurrent inhibition improves physiological tremor by reducing corticomuscular coupling at $10 \mathrm{~Hz}$. J Neurosci. 2009; 29(20):6616-6624. [PubMed: 19458232]

Windhorst U. On the role of recurrent inhibitory feedback in motor control. Prog Neurobiol. 1996; 49(6):517-587. [PubMed: 8912393]

Wootz H, Enjin A, Wallen-Mackenzie A, Lindholm D, Kullander K. Reduced VGLUT2 expression increases motor neuron viability in Sod1(G93A) mice. Neurobiol Dis. 2010; 37(1):58-66. [PubMed: 19770042] 

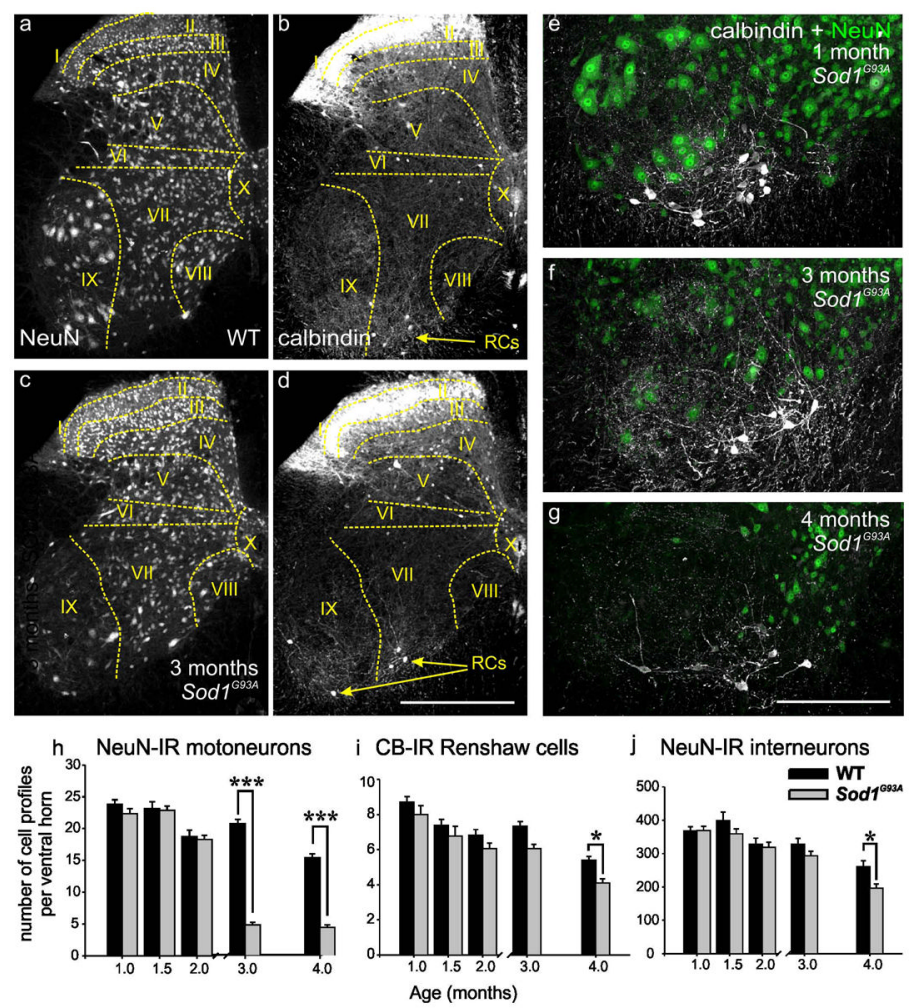

Figure 1.

Decreases in the number of NeuN-IR motor neurons occur before and are more intense than decreases in calbindin-IR Renshaw cells. (a-d) Low magnification confocal microscopy images of NeuN-IR cellsand calbindin-IR cells in the lumbar 5 segment of a WT (a-b) and a Sod1 ${ }^{G 93 A}$ spinal cord (c-d), both 3 months of age. Laminar boundaries are drawn according to NeuN-immunoreactivity and established cytoarchitectonic criteria. Calbindin-IR Renshaw cells (RCs) are indicated in ventral LVII and LIX (arrows in b and d). (e-g) Ventral horn of Sod1 ${ }^{G 93 A}$ mice of 1, 3 and 4 months showing NeuN (green) and calbindin (white) immunoreactivities. NeuN-IR motor neurons are depleted in 3 and 4 months animals, but most calbindin-IR Renshaw cells remain. (h) Quantification of the number of NeuN-IR motor neurons, (i) calbindin-IR Renshaw cells and (j) ventral horn NeuN-IR interneurons per ventral horn in $50 \mu \mathrm{m}$ thick sections. Black and grey bars are wildtype and $S o d 1^{G 93 A}$ averages obtained by pooling data from 2-4 animals at each age. Significant depletions in the number of NeuN-IR motor neurons were found at 3 and 4 months of age (asterisks, $\mathrm{p}<0.001$ one-way ANOVA, post-hoc Bonferroni corrected tests). Depletions in the number of Renshaw cells and interneurons are smaller and are significant at 4 months of age (asterisks, p <0.05). Error bars indicate SEMs. Scale bars: in d, $500 \mu \mathrm{m}$ (also for $\mathbf{a}-\mathbf{c}$ ); in $\mathbf{g}$, $200 \mu \mathrm{m}$ (also for $\mathbf{e}$ and $\mathbf{f}$ ). (A version of this figure in which white-green has been changed for magenta-green is supplied as supplementary figure 1). 


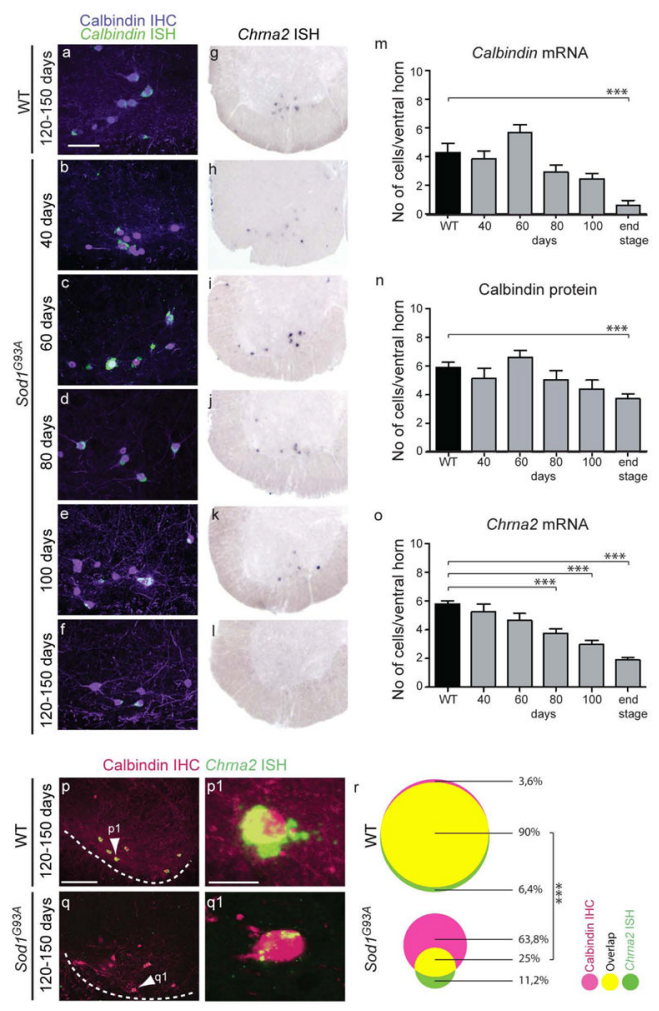

Figure 2.

Expression of calbindin and chrna2 downregulate with different time courses in Renshaw cells as disease progresses. (a-f) Images of ISH/IHC double staining using a calbindin probe (green) and calbindin antibodies (purple) in the ventral horn Renshaw cell area of lumbar spinal cord sections from WT and $\operatorname{Sod} 1^{G 93 A}$ mice at day 40, day 60, day 80, day 100 and end stage (120-150 days). (g-l) Brightfield images of ISH using a chrna2 probe at the same ages. Quantifications demonstrate that the number of cells expressing calbindin mRNA (m) as well as the number of cells expressing calbindin protein (n) are only decreased at disease end stage compared to WT ( $\mathrm{p}<0.001$ one-way ANOVA, post-hoc Bonferroni tests of all ages). In contrast, the number of chrna 2 mRNA expressing cells (o) are significantly decreased by day 80 and continued to decrease at day 100 and at end stage compared to WT (all p<0.001, tests as above). Note a more profound downregulation of calbindin mRNA (m) compared to calbindin immunoreactivity (n). (p-q) Double IHC/ISH of calbindin (pink, IHC) and chrna2 (green, ISH) on lumbar spinal cord from WT (p) and $\operatorname{Sod} 1^{G 93 A}$ mice at end stage (120-150 days old) (q). High magnification images of WT (p1) and Sod1 ${ }^{\text {G93A }}$ (q1) show Renshaw cells co-expressing calbindin and chrna2. Note decreased expression of chrna2 in $\operatorname{Sod} 1^{G 93 A}$ and thus fewer co-localization with calbindin immunoreactivity. (r) Venn-diagrams illustrate the relative sizes of cell populations expressing either calbindin (pink circles), chrna2 (green circles) or both (yellow circles) for WT or $\operatorname{Sod} 1^{G 93 A}$ mice at end stage. The number of calbindin-IR cells in the ventral Renshaw area significantly decreased by $42 \%$ in $\operatorname{Sod} 1^{G 93 A}$ mice compared to WT, chrna2 positive cells decreased by $77 \%$ and thus cells showing co-localization between both markers decreased by $83 \%$; from $93.5 \%$ in WT to $28 \%$ in $\operatorname{Sod} 1^{G 93 A}$ mice ( $<<0.001$ for all markers, t-tests). At end stage, the number of calbindin-IR cells in the Renshaw area was significantly higher than the number chrna2 positive cells $(\mathrm{p}<0.05)$ or cells with co-localization of both markers $(\mathrm{p}<0.01$, not indicated in the figure one-way ANOVA, post-hoc Bonferroni tests). No significant differences were detected in WTs. Error bars indicate SEMs. Error bars indicate SEMs. 
Scale bars: in d,500 $\mu \mathrm{m}$ (also for a-c); in $\mathbf{g ,}, 200 \mu \mathrm{m}$ (also for $\mathbf{e}$ and $\mathbf{f}$ ); in $\mathbf{p}, 100 \mu \mathrm{m}$ (applies also to $\mathbf{q}$ ); in $\mathbf{p 1}, 25 \mu \mathrm{m}$ (applies also to q1).(A version of this figure in which red-green has been changed for magenta-green is supplied as supplementary figure 2). 


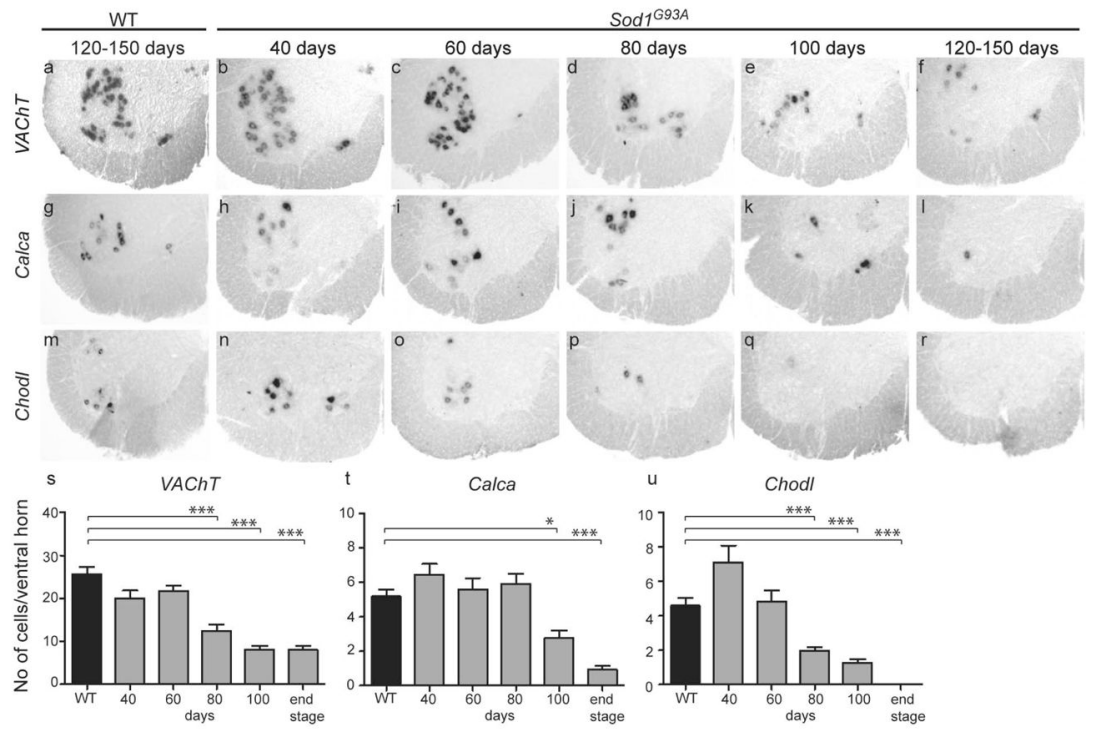

Figure 3.

Different motor neuron genes downregulate with different time courses as disease progresses. (a-f) VAChTISH staining of lumbar spinal cord sections from WT and Sod1 ${ }^{G 93 A}$ mice. (g-r) ISH for two different genes expressed in fast motor neurons: Calca and Chodl. Experiments were carried out in adult WT mice and in $\operatorname{Sod} 1{ }^{G 93 A}$ mice at day 40, $60,80,100$ and end stage (120-150 days). (a-f and s) The number of $V A C h T$ positive cells was significantly decreased in 80 day old $\operatorname{Sod} 1^{G 93 A}$ mice compared to WT and remained decreased at a similar level at 100 days and end stage ( $<<0.001$, one-way ANOVA, post-hoc Bonferroni tests). (g-r and $\mathbf{t}, \mathbf{u})$ Expression of the two fast motor neurons genes, Calca and Chodl, were affected differently during disease progression. The number of Calca positive cells was first significantly decreased at day $100(\mathrm{p}<0.05, \mathbf{t})$ while the number of $C h o d l$ positive cells was decreased already at day $80(\mathrm{p}<0.001, \mathbf{u})$. Both genes continue to progressively downregulate towards end-stage ( $(\mathbf{t}$ and $\mathbf{u})$ and no Chodl expression was detected at end-stage. Error bars indicate SEMs. 

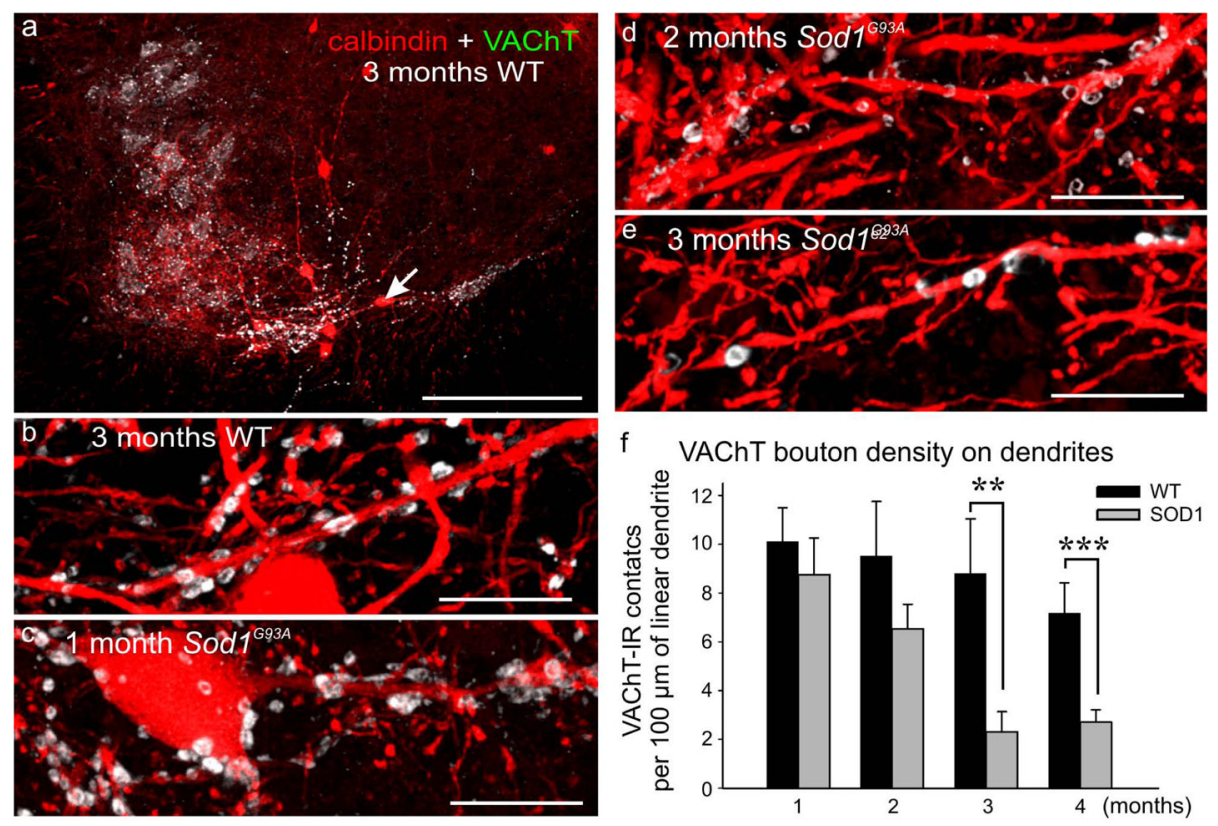

Figure 4.

VAChT-IR synapses on Renshaw cells are profoundly altered in $\operatorname{Sod} 1^{G 93 A}$ mice, starting at 2 months of age. (a) Low and (b) high magnification confocal images of VAChT immunoreactivity (green) and Renshaw cells (red) in WT animals. (c-e) Images of calbindin-IR Renshaw cell dendritesin 1, 2 and 3 month old Sod1 ${ }^{G 93 A}$ mice. VAChT-IR fills most boutons in contact with WT Renshaw cells VAChT-IR boutons of 2 month Sod1 $1^{G 93 A}$ animals appear hollow and the immunoreactivity concentrates at the periphery of the bouton (e). Few boutons remain in 3 month $\operatorname{Sod} 1{ }^{G 93 A}$ mice. (f) Quantification of VAChT-IR contacts on Renshaw cell dendrites. No significant differences in contact density were found in WTs of different ages ( $\mathrm{p}=0.653$, One-Way ANOVA). Contact density was significantly reduced in 3 month ( $\mathrm{p}<0.01$, Bonferroni corrected t-test) and 4 month ( $<<0.001$, Bonferroni corrected t-test)old $\operatorname{Sod} 1^{G 93 A}$ animals compared to their age-matched controls, but not in 1 and 2 month Sod1 ${ }^{G 93 A}$ animals. Error bars indicate SEMs. Scale bars: in $\mathbf{a}, 250 \mu \mathrm{m}$; in b-e, $10 \mu \mathrm{m}$.(A version of this figure in which white-green has been changed for magenta-green is supplied as supplementary figure 3 ). 

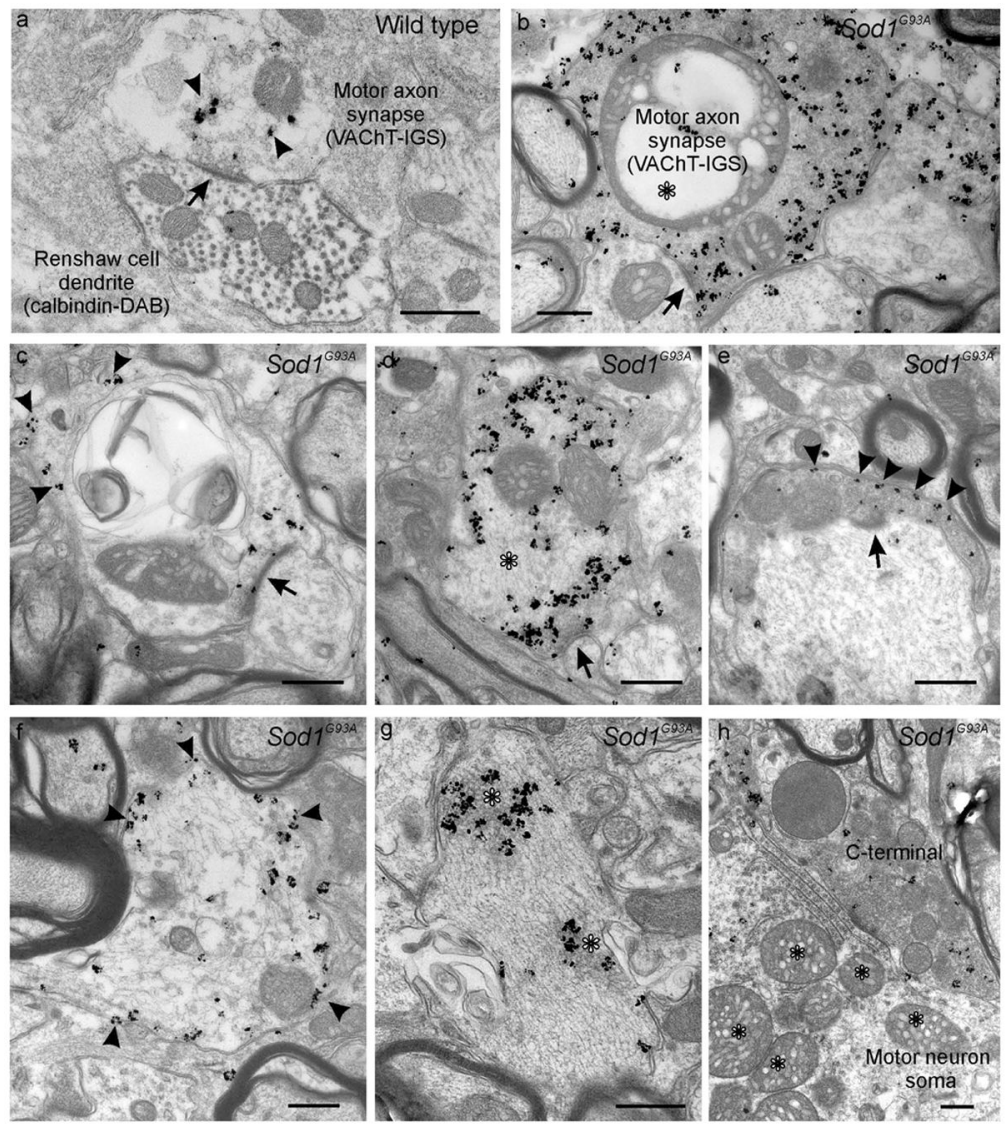

\section{Figure 5.}

Alterations in the ultrastructure of motor axon VAChT-IR synapses in $\operatorname{Sod} 1^{G 93 A}$ mice of 2.5 months of age. (a) WT VAChT-IR terminal (immunogold-silver particles, arrowheads) making a synapse (arrow) on a calbindin-IR dendrite (filled with electron dense DAB precipitate). Immunoreactivity is associated with synaptic vesicles distributed in the center of the bouton and at the presynaptic active zone. (b,c,d) Motor axon synaptic boutons (arrows indicate postsynaptic densities) in Sod1 ${ }^{G 93 A}$ mice containing VAChTimmunoreactivity displaced to the periphery of the terminals. (b) Bouton containing a large and expanded mitochondria with increased intramembrane spaces and vacuolization (asterisk)typical of motor neurons in Sod1 ${ }^{G 93 A}$ mice of this age. (c) Motor axon synaptic bouton with a degenerated central structure and VAChT-immunoreactivity close to the synapse (arrow) or in the periphery of the terminal (arrowheads). (d) Peripheral displacement of VAChT-IR synaptic vesicles due to neurofilamen to us aggregations (asterisk) and mitochondrial expansion at the center of the terminal. (e) Synaptic terminal with no obvious degenerating central structure, but also displaying most VAChTimmunoreactivity close to the plasma membrane (arrowheads). (f) Non-synaptic motor neuron axonal varicosity with VAChT-immunoreactivity preferentially on the plasma membrane, frequently without discernible evidence of vesicle accumulations (arrowheads). (g) Motor axon with neurofilament accumulations and clumped VAChT-IR vesicles associated with the plasma membrane (asterisks). (h) Part of motor neuron cell soma (note abnormal mitochondria, asterisks) receiving a synapse from a VAChT-IR C-terminal without major structural anomalies and normal mitochondria. C-terminals are originated from interneurons, not motor neurons. All scale bars are $0.5 \mu \mathrm{m}$. 

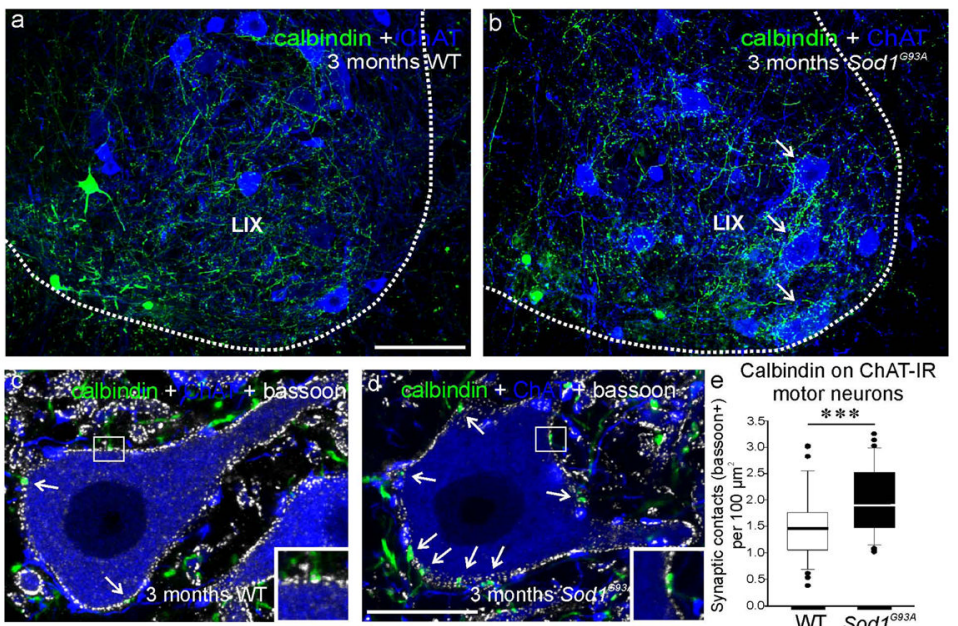

Calbindin on ChAT-IR
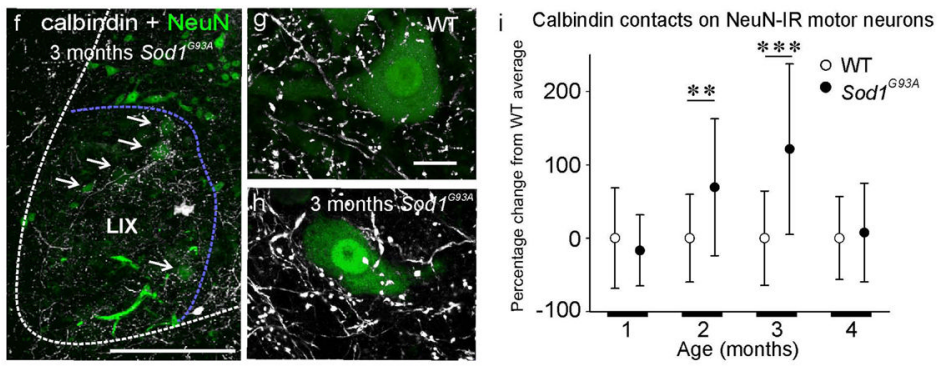

Figure 6.

Renshaw cell calbindin-IR axons in relation to motor neurons. (a-b) Low magnification confocal image of calbindin-IR axons (green, FITC) and ChAT-IR motor neurons (blue, Cy5) in 3 months old WT and a Sod1 ${ }^{G 93 A}$ mouse. Note increased density of calbindin-IR axons over certain motor neurons in the $\operatorname{Sod} 1^{G 93 A}$ mouse. (c-d) Higher magnification single optical confocal section images of calbindin-IR axons and ChAT-IR motor neurons also showing bassoon immunoreactivity (white, Cy3). All calbindin varicosities in contacts with the motor neurons surface (arrows) contain bassoon demonstrating the presence of a synaptic active zone (insets). (e) Box and whisker plot of the density of synaptic (bassoon+) calbindin contacts on the somata of ChAT-IR motor neurons. Sample contains 36 motor neurons in each group and the plot shows the median value(line), 75th (upper box), 25th (lower box), 10th and 90th(error bars) percentiles and position of the outliers (individual data points). Note presence of statistical significance (asterisksi ndicate $\mathrm{p}<0.001$, t-tests) despite high variability in contact density from motor neuron to motor neuron. (f) CalbindinIR axons and NeuN-IR motor neurons in a3 month $\operatorname{Sod} 1^{G 93 A}$ mouse. Areas devoid of NeuN-IR cell bodies show decreased density of calbindin-IR axons and these concentrate in regions with remaining NeuN-IR motor neurons (arrows). (g-h) Collapsed 3D images of examples of calbindin-IR axons and varicosities surrounding NeuN-IR motor neurons in WT (g), and 3 months $\operatorname{Sod} 1^{G 93 A}$ motor neurons (h). (i) Percentage change with respect to the WT averages of calbindin-IR contact density around motor neuron cell bodies. WTs and 1 and 4 month $\operatorname{Sod} 1^{G 93 A}$ mice show similar variability and average densities. Error bars represent SDs. Sod ${ }^{G 93 A}$ animals at 2 and 3 months of age show significant increases in contact density compared to their age-matched WTs $(\mathrm{p}<0.01$ and $\mathrm{p}<0,001$, respectively, $\mathrm{t}-$ tests) and also higher standard deviations (error bars) suggesting large variability (cells varied from $50 \%$ decrease to $>350 \%$ increases in contact density with respect their agematched WT average). Scale bars: in $\mathbf{a}, 100 \mu \mathrm{m}$ (b is at the same magnification); in $\mathbf{d}, 20 \mu \mathrm{m}$ (c is at the same magnification); in $\mathbf{f}, 250 \mu \mathrm{m}$; in $\mathbf{g , 2 0} \mu \mathrm{m}$ (h is at the same magnification). 

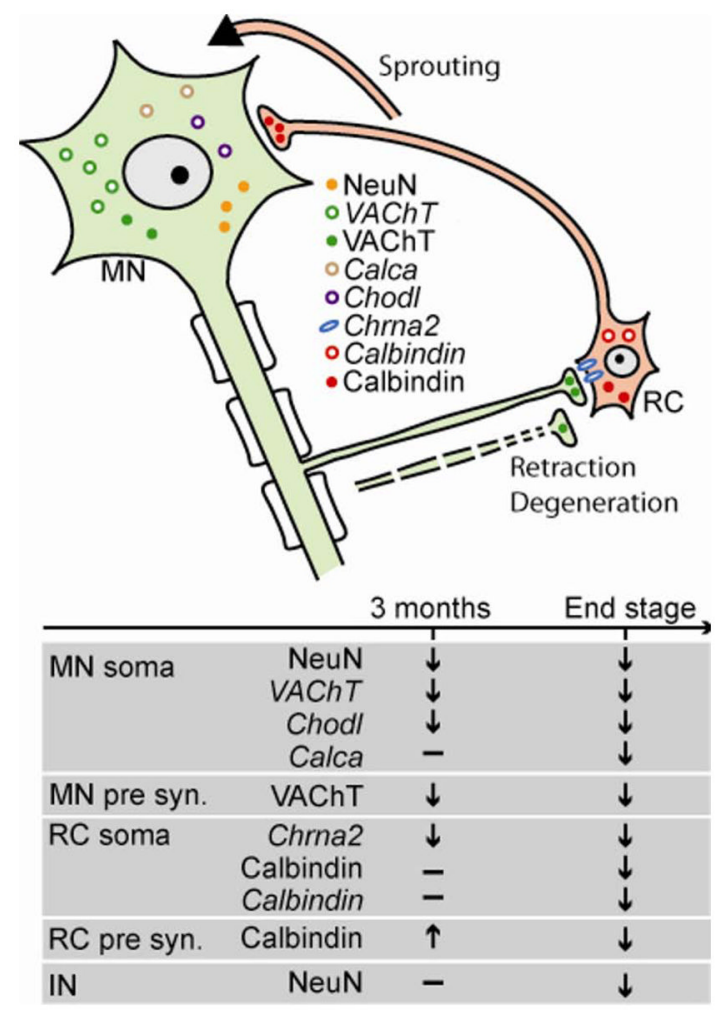

Figure 7.

Schematic drawing summarizing the changes in motor neuron and Renshaw cells during disease progression. In a motor neuron cell body, NeuN and VAChT together with the fast motor neuron marker Chodl decrease first and Calca decreases later. In the receiving Renshaw cell body, Chrna2 decreases before a decrease in Calbindin can be detected. Simultaneously with these changes in gene expression motor axon synapses on Renshaw cells become abnormal and dennervate Renshaw cells dendrites, while Renshaw cell synapses seem to undergo compensatory innervation of remaining NeuN-IR motor neurons. 


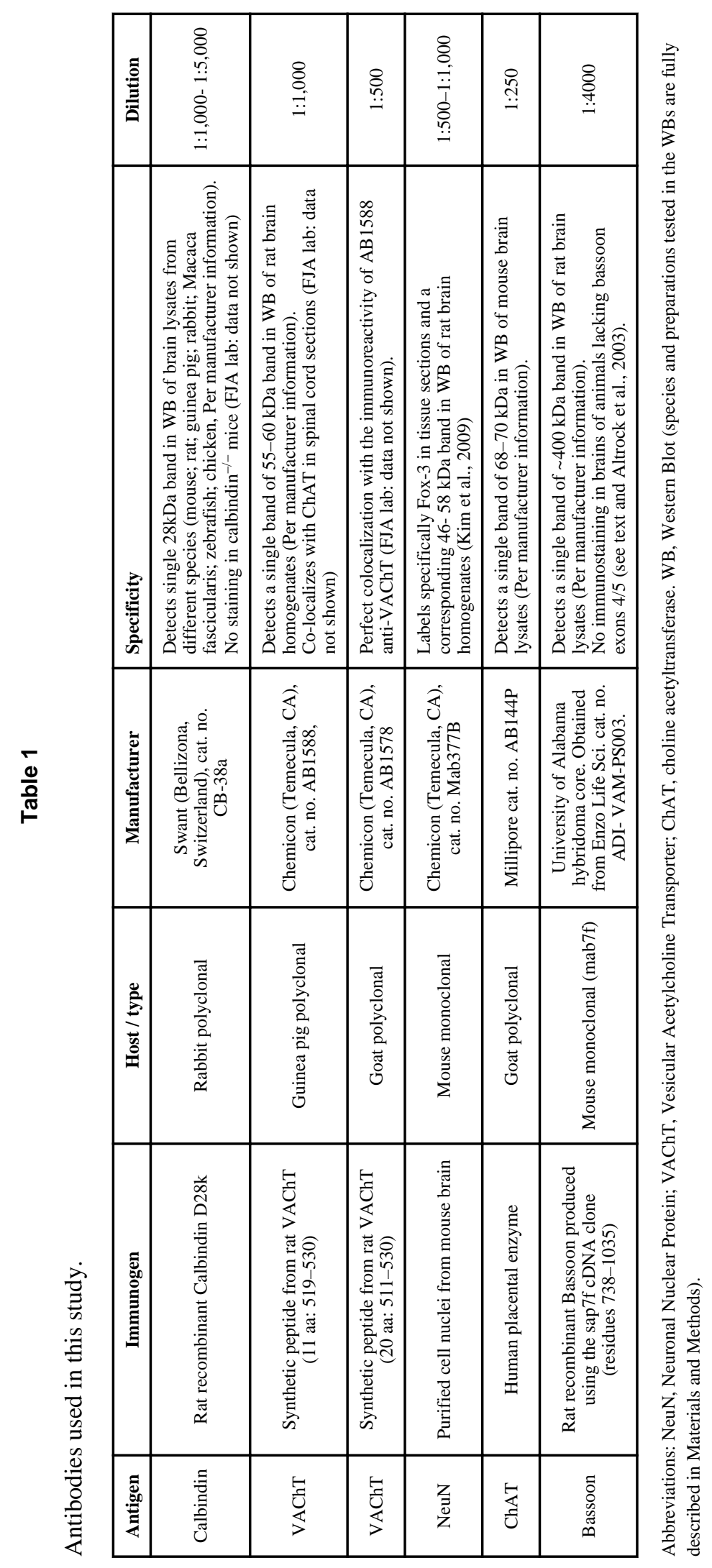

J Comp Neurol. Author manuscript; available in PMC 2014 May 01. 